\title{
Was the Right to Keep and Bear Arms Conditioned on Service in an Organized Militia?
}

Randy E. Barnett

Georgetown University Law Center, rb325@law.georgetown.edu

This paper can be downloaded free of charge from:

https://scholarship.law.georgetown.edu/facpub/849

http://ssrn.com/abstract=420981

83 Tex. L. Rev. 237-277 (2004) (reviewing H. Richard Uviller \& William G. Merkel, The Militia and the Right to Arms, or, How the Second Amendment Fell Silent (2002))

This open-access article is brought to you by the Georgetown Law Library. Posted with permission of the author. Follow this and additional works at: https://scholarship.law.georgetown.edu/facpub

Part of the Constitutional Law Commons 


\title{
Book Review Essay
}

\section{Was the Right to Keep and Bear Arns Conditioned on Service in an Organized Militia?}

\author{
The Militia and the Right to ARMS, OR, How the Second \\ Amendment Fell Silent. By H. Richard Uviller ${ }^{\dagger}$ and William G. \\ Merkel. ${ }^{\dagger \dagger}$ Durham: Duke University Press, 2002. Pp. xii, 340. \\ $\$ 19.95$.
}

\section{Reviewed by Randy E. Bamett}

Those who deny that the original meaning of the Second Amendment protected an individual right to keep and bear arms on a par with the rights of freedom of speech, press, and assembly no longer claim that the amendment refers only to a "collective right" of states to maintain their militias. Instead, they now claim that the right, although belonging to individuals, was conditioned on service in an organized militia. With the demise of organized militias, they contend, the right lost any relevance to constitutional adjudication. In this Essay, I evaluate the case made for this historical claim by Richard Uviller and William Merkel in their book, The Militia and the Right to Arms, or, How the Second Amendment Fell Silent. I also evaluate their denial that the original meaning of the Fourteenth Amendment protected an individual right to arms unconditioned on militia service. I find both claims inconsistent with the available evidence of original meaning and also. perhaps surprisingly, with existing federal low.

Who says that even heated conflicts over constitutional meaning can never progress? Over the past ten years, the intellectual clash between those who claimed that, at the time of the founding, the "right to keep and bear arms" protected by the Second Amendment was a "collective right" of the states to preserve their militia and those who maintain instead that it originally referred to an individual right akin to the others protected in the Bill of Rights has been resolved. That the individual right view prevailed definitively is evidenced by the fact that no Second Amendment scholar, no matter how inimical to gun rights, makes the "collective right" claim any more. All

$\dagger$ Arthur Levitt Professor of Law Emeritus, Columbia University.

†† J.D. Columbia Unjuersity.

* Austin B. Fletcher Professor, Boston University School of Law, rbanett@bu.edu. This Essay was originally presented at a symposium at the William \& Mary School of Law in January of 2003. I thank Joseph Olson and Jim Lindgren for their helpful suggestions. I am also grateful for helpfill comments made during faculty workshops at Seton Hall University and George Mason University law schools. Pennission to photocopy for classroom use is hereby granted. 
now agree that the Second Amendment originally referred to the right of the individual.'

Indeed, the fact that the collective right theory was once so confidently advanced by gun control enthusiasts ${ }^{2}$ is on its way down the collective mem. ory hole as though it had never been asserted. With its demise, the intellectual debate over the original meaning of the Second Amendment has turned in a different direction. Although now conceding that the right to keep and bear arms indeed belongs to individuals rather than to states, almost without missing a beat, gun control enthusiasts now claim with equal assurance that the individual right to bear arms was somehow "conditioned" in its exercise on participation in an organized militia.

The "militia-conditioned individual right" theory represents an advance for the anti-gun-rights position. It obviates (a) the copious evidence, both direct and circumstantial, that "the right to keep and bear arms" belonged to individuals ${ }^{3}$ and (b) the lack of any direct evidence that the Second Amendment protected some sort of a never-very-well-specified power of states, while (c) allowing opponents of gun rights to maintain, as they did with the "collective right" theory, that the Second Amendment is irrelevant to the constitutionality of modern gun laws. But is the theory supported by the available evidence?

The latest to make this historical claim are Richard Uviller and William Merkel. In their book, The Militia and the Right to Arms, or, How the Second Amendment Fell Silent, Uviller and Merkel reject the collective right theory and characterize the Second Amendment "right to keep and bear arms" as an individual right. ${ }^{4}$ However, they firther claim that, because the right to arms may be exercised only while participating as part of an organized militia, ${ }^{5}$ its existence as a constitutional right is conditioned on the continued existence of a well-regulated militia. With the demise of the organized militia, so too has vanished the right to keep and bear arms. In their

1. The viewpoint of Uviller and Merkel is representative: "[W]e cannot join ... in the contention that the eonstiutional right to arms belongs to the states rather than to natural persons. . . This reading is, we think, misguided." H. RICHARD UVILLER \& WILlIAM G. MERKEL, THE Militia AND tHE RIGHT TO ARMS, OR, HOW THE SECOND AMENDMENT FELL SileNt 179 (2002).

2. E.g., Car! T. Bogus, The Hidden History of the Second Amendment, 31 U.C. DAVIS L. REV. 309,408 (1998) (asserting that "to the extent original intent matters, the hidden history of the Second Amendment strongly supports the eollective rights position").

3. For a succinct summary of this evidence, which has been developed by scholars over the past ten or more years, sec United States v. Emerson, 270 F.3d 203, 236-59 (5th Cir. 2001).

4. UVtLLER \& MERKEL, supra note 1, at 23 "'From the text as well as a fair understanding of the contemporary ethic regarding ams and liberty, it seens to us ovenwhelmingly evident that the principal purpose of the Amendment was to secure a personal, individual entitlement to the possession and use of arms.").

5. Id at 31 ("To rekm to our central theme, then, the individual right to keep and bear anns that is secured in the Second Amendment in our analysis is a right without application outside the context of service in state or federal militia.") 
words, "historical developments have altered a vital condition for the articulated right to keep and bear anns.",6

In this Essay, I will comment briefly on the authors' interpretive methodology before moving on to discuss specific problems with their effort to interpret the Second Amendment. One of the peculiarities of the modern debate over the Second Amendment is its single-minded preoccupation with the issue of original meaning or original intent. This is odd because, to my knowledge, none of the right-limiting theorists are themselves originalists, and consequently they would surely not limit, for example, their interpretation of the First Amendment by its original meaning. But as the modern academic debate over the Second Amendment is entirely a historical one, in this Essay I limit my attention to this issue.

I will confine myself to evidence, some previously unconsidered in this debate, that specifically disproves that the Second Amendment protected a militia-conditioned individual right. I do not reiterate here the other direct and circumstantial evidence that supports an individual, as opposed to a "collective," right, but the full strength of the individual-right position cannot fully be appreciated without taking that evidence into account.

\section{The Authors' Originalism}

Uviller and Merkel (hereinafter "the authors") are to be commended for explicitly discussing their method of interpretation. ${ }^{8}$ Few law professors and even fewer historians so much as attempt this. Unfortunately, I found their discussion of interpretation rather confused. Increasingly, originalists like myself focus entirely on the original meaning of the text - the meaning that a reasonable speaker of the language would have attached to the words at the time of the text's enactment. ${ }^{9}$ What did "militia" mean in I79I? Or "wellregulated" of "arms" or "bear" or "right" of "the people"? Of course, speakers then, like speakers today, would be influenced by the context in which a particular word or phrase is used. For example, because of the context of the Second Amendment, we can be quite sure that the term "arms" refers to weapons, not the appendages to which our hands are attached.

Disceming the original public meaning of the text requires an examination of linguistic usage among those who wrote and ratified the text as well as the general public to whom the Constitution was addressed.

6. Id. at 35

7. See Emerson, 270 F.3d at $236-59$ (surveying that other evidence).

8. UVILLER \& MERKEL, supre note 1, at 147-67.

9. I explain the version of originalism described in this Patt in RANDY E. BARNETT, RESTORING THE LOST CONSTITUTION: THE PRESUMPTION OF LIBERTY 89-130 (2004) [hereinafter BARNETT, RESTORING I. There, I defend original-meaning originalism as entailed by the commitment to a written constitution-a structaral feature of the U.S. Constitution (like federalism or separation of powers) that is needed to impose law on those who make, enforce, and interpret legislation that they then iunpose on the citizenry. For a written constitution to fulfill the function of providing a higher law, its uneaning must reunain the same until it is properly changed. 
Evidence of specialized meaning or intent by framers or ratifiers is only relevant if it is shown that such specialized meaning would have been known and assumed by a member of the general public. Where more than one contemporary meaning is identified, it becomes necessary to establish which meaning was dominant. Any such historical claim is an empirical one that requires actual evidence of usage to substantiate. If possible, one should undertake a quantitative assessment to distinguish normal from abnormal usage. $^{10}$

Of course, once discerned, the original pubIic meaning of the text, like the public meaning of laws enacted yesterday, must be applied to the facts of particular cases. Though general language of the sort used in the Constitution may exclude many possible outcomes, often it does not dictate a unique result, thus leaving to those actors that apply original meaning to particular cases and controversies considerable discretion in developing legal doctrines. This activity of applying meaning to cases by means of intermediary doctrines is better described as constitutional construction, rather than as interpretation of text. ${ }^{11}$ The need for construction is the unavoidable cost of using language, especially general abstract language, to guide behavior. On the other hand, the benefit of general language is that, even with no deviation from its original meaning, it can last a very long time without becoming antiquated.

Sometimes it sounds like the authors are endorsing an original-publicmeaning approach, but that is not what they practice. In particular, the authors present very little evidence of the public meaning of the words used in the Constitution and, where disagreement exists, little quantitative evidence by which to distinguish dominant from deviant meaning. They seem instead to be searching for what is better described as original intent, rather than original meaning.

Those originalists who favor original intent want to fill the gaps in the original public meaning and cabin the discretion of those engaged in construction of abstract provisions by appealing to the specific intentions of those who either wrote or ratified them. This version of originalism has been

I0. I offer elisewhere such a quantitative assessment of the meaning of the words "commerce" and "regulate." Randy E. Bamett, New Evidence of the Original Meaning of the Commerce Clause, 55 ARK L. REV. 847 (2003); Randy E. Bamett, The Original Meaning of the Commerce Clause, 68 U. CHI. L. REV. IOI (200I) [hereinafter Bamett, The Original Meaning of the Commerce Clause]. Such a quantitative survey is not always possibie, however, given the state of the evidence of the particular word at issue. For example, the term "necessary" is too common to establish by quantitative survey a dominant pubilic meaning to which the Necessary and Proper Clause must have referred. One must then fall back on more waditional reliance on statements of various participants in the historical period about the clause in question. See, e.g., Randy E. Bamett, The Original Meaning of the Necessary and Proper Clause, 6 U. PA. 3. CONST. L. 183 (2003) (analyzing statements made by Madison, Hamilton, Jcfferson, Marshall, and others for evidence of the original meaning of the words "necessary" and "proper").

11. On the distinction between interpretation and construction, see BARVEr, supra note 9, at II8-30. 
roundly criticized for reasons that I shall not repeat here, many of which I think are sound. ${ }^{12}$ Given the fact that the Framers did not actually contemplate most instances in which their words would be applied, in practice the search for specific original intentions usually consists of what I call "channeling the framers" to discem what they "would have" thought of a particular case or controversy. This converts originalism from a historical and factual inquiry into a speculative and counterfactual one. There is simply no factual answer to the question of what the founders would have thought of a particular matter. For this reason, such claims can neither be empirically established nor refuted.

While in places, the authors appear to reject this approach-for example, when they repeatedly cite the work of $\mathrm{H}$. Jefferson Powell with approval $^{13}$ - this rejection is not practiced consistently, ${ }^{14}$ as demonstrated by their heavy and uncritical reliance on the works of such original-intent authors as Raoul Berger. ${ }^{15}$ The authors also seem to be unaware that the historical evidence cited by Powell actually supports the conclusion that the founding generation, while rejecting original-intent originalism, ended up favoring original-meaning interpretation. ${ }^{16}$

Finally, in contrast with both original-meaning and original-intent originalists, there are the new fangled "translation theory" originalists, such as Larry Lessig and William Michael Treanor, who start with original meaning or intent (it is not always clear which) to discem the principles underlying the text, and then purport to "translate" those principles-but not the text itself-into the modem day context. ${ }^{17}$ While this does not sound like the method that the authors endorse, nor practice in most cases, they nevertheless cite Larry Lessig's work with approval without seeming to appreciate the difference between his approach and that of other originalists. ${ }^{18}$

As I said, their discussion of methodology is confusing, but perhaps no more so than the well-known historian Jack Rakove, a nonoriginalist, whose discussion of interpretive methodology the authors say they found helpful. ${ }^{19}$

12. Seeid at 89-9!, 113-i6.

13. UVILLER \& MERKEL, supra note 1, at 148, 154, 296 n.6, 299 n.36.

14. See, e.g., id. at 98 ("By inference, as well as from the record of debate in the House, the process casts light on the Amendment's intended meaning.").

15. See, e.g., id. at 205-06 (discussing Berger's criticism of Professor Akhil Reed Amar's thesis related to the Fourteenth Amendment's effiect on the Second Amendment).

16. See BARNETT, supra note 9, at 94-100.

17. See, e.g., Lawrence I essig, Understanding Changed Readings: Fidelity and Theory, 47 STAN. L. REV. 395, 400 (1995) (arguing that the context in which text was created, along with the context in which text must be applied, should be considered in order to understand the text's meaning); William Michael Treanor, The Original Understanding of the Takings Clause and the Political Process, 95 ColluM. L. REV. 782, 859-80 (1995) (applying "wanslation theo:y" to the Takings Clause).

18. See UVILLER \& MERKEL, supra note 1, at 296 n.6.

19. The authors rely on Professor Rakove's work several times in the book. Id. at $80,177,246$ n. 9,273 n. 140,292 n. 54. 
Uviller and Merkel seem not to realize that originalism has quite differing and competing strains or, if they do, they do not consistently keep within one method or another. Their erratic methodology renders it hard to respond to their interpretive claims since they might, for example, present evidence of intent that, while valid as far as it goes, is irrelevant to the public meaning of the text or, at a minimum, is not dispositive.

As it turns out, the obvious source of this confusion stems from the fact that the authors are not themselves originalists, although they never disclose this to the reader. ${ }^{20}$ They therefore fall into the large class of nonoriginalists who make originalist arguments, one assumes, to persuade others who care more about original meaning than they do. This probably describes every opponent of the individual-rights interpretation of the Second Amendment who offers historical evidence that this interpretation is in error. ${ }^{21}$ Even the professional historians who insist on a crabbed originalist interpretation of the right to bear arms, a right of which they disapprove, would never think to apply this method to limit other constitutional rights that they like. ${ }^{22}$

If, however, as the authors themselves believe, courts need not and often should not follow original meaning, then courts are perfectly free to adopt a robust individual-rights interpretation of the Second Amendment even if this should contradict its original meaning. Uviller and Merkel do not, of course, consider this implication of rejecting originalism.

So far as 1 could tell, the authors present no new cvidence of the original meaning of the Second Amendment and confine themselves to reliance on

20. I leamed for the first time that they are not originalists during their talks at the symposium on their book held at the William \& Mary School of Law. Until that moment, I had assumed from the book that they were. I was pezhaps misled by their statement near the beginning of the book that: "Our historical approach is simply this: we take seriously the words chosen by the drafters, and seek their meaning to the ratifying generation." Id. at 37. Perhaps like other readers, 1 took this to describe their approach to constitutional interpsetation.

21. See, e.g., Carl T. Bogus, The Hidden History of the Second Amendment, 3I U.C. DAvis L. REV. 309, 369, 362-69 (1998) (arguing that "Madison's objective in writing the Second Amendment was not to grant an individual right but to set limits on congressional power"); Keith A. Erhman \& Dennis A. Henigan, The Second Amendment in the Twentieth Century: Hove You Seen Your Militia Lately?, 15 U. DAYTON L. REV. 5, 24, 18-24 (1989) (concluding that "in the context of the Constitution, the militia was viewed as a state-organized, state-run body" and that "[t]his distinction between the militia as a state-organized body and as the entire citizenry at large is important in understanding the Second Amendment because one of the central clamis of those who oppose govemment efforts to regulate firearms is that the 'militia' referred to in the Constitution simply means an armed citizenty at large").

22. I know of no historian or law professor who, in offering an originalist critique of the individual rights position, has ever used an originalist method to limit the scope of any other right in the Bill of Rights, though someone may have escaped my attention. Historian lack Rakove, the author of Original Meanings: Politics and ldeas in the Making of the Constitution (1997), for example, has never claimed to be an originalist. See, e.g., Jack N. Rakove, Words. Deeds, and Guns: ARMING AMERICA and the Second Amendment, 59 WM. \& MARY Q. 205, 206 (2002) ("[1]t would be difficult to identify any clause of the Constitution more open to the common sense objection that its modem interpretation should not be rooted in the concept of 'original intent' or 'original understanding,' simply because frearms are now far more devastating than anyone in the eighteenth century could have plausibly imagined."). 
secondary sources or evidence already well-known to Second Amendment scholars of all stripes. There is nothing wrong with offering a new interpretation of previously discussed evidence, of course, but readers should not expect to find anything that has not been previously considered by other writers in the field. Nothing new has been uncovered to change the debate. And unfortunately for a book-length work, the authors do not treat comprehensively all the available evidence of original meaning. This is particularly regrettable as the quantity of such historical evidence is manageable enough that all of it could have been evaluated in the space of a monograph.

Let me tum now from generalities to particulars, for it will come as no surprise to those familiar with my writings in this area ${ }^{23}$ to learn that I am not persuaded by the authors' originalist arguments and therefore disagree with their conclusions. Because most of the book is taken up by a lengthy, and largely uncontroversial, history of the militia before and after the adoption of the Constitution, along with a discussion of classical republicanism, the book's treatment of the Second Amendment is actually rather brief. ${ }^{24}$ Their conclusion that the individual right to arms is conditioned on service in an organized militia rests on a few claims that I shall treat separately.

First is the claim that "bear arms" had an exclusively military connotation. Second, that, as a textual matter, the first part of the amendment places a condition on the exercise of the right specified in the second part. ${ }^{25}$ Third, that the "Privileges or Immunities" of the Fourteenth Amendment do not include the protection of an individual non-militia-based right to keep and bear anns. ${ }^{26}$ Fourth, that the practical significance of finding the right to bear arms to be an unconditional individual right is to protect an absolute right to be free of any regulation whatsoever, no matter how reasonable. Though this last claim hardly seems relevant to the authors' historical claims, they repeat it in sometimes intemperate tones throughout the work. ${ }^{27}$ Finally, the authors conclude that the general militia referenced in the Second Amendment no longer exists. ${ }^{28}$ On all five counts, they err.

\section{Was "Bear Anns" Exclusively a Military Tern?}

The authors claim that: "Bearing anns implied making muster, equipped and ready for service; keeping entailed steady readiness to serve when called to duty."29 For this proposition they reference with uncritical approval Garry Wills's essay in The New York Review of Books in stating that "bearing amns

23. E.g., Randy E. Banett \& Don B. Kates, Under Fire: The New Consensus on the Second Amendment, 45 EMORY L.J. I139 (1996).

24. UVILL ER \& MERKEL, supra note 1, at 24-27.

25. Id. at 149-50.

26. Id. at 204-07.

27. Id. at $1,9,11,37,54,83,169,197$.

28. Id. at $109-44$.

29. Id. at 39 . 
had, from its earliest recorded employment and through the late eighteenth century, an exclusively military connotation." ${ }^{30}$ From Wills the authors conclude that "the verb 'to bear' ... would not have been used in the eighteenth century - as it would not commonly be today - to connote purely private use of arms." ${ }^{31}$

It is not enough, however, to present numerous examples of the use of "bear arms" in a military context to demonstrate that this is its exclusive use. Claims of exclusivity are hard to establish empirically because it must be shown that there are no other competing uses of a particular word. Just a few counterexamples call such a claim into question and then force those making it to do a systematic survey to distinguish normal from abnormal or deviant uses. Individual-rights scholars have pointed to several instances of the term "bear arms" being used in a nonmilitary context. ${ }^{32}$

\section{A. Early Uses of "Bear Arms" Outside the Military Context}

One important example, overlooked by the authors, is $A$ Bill for the Preservation of Deer drafted by Thomas Jefferson and presented by James Madison to the Virginia General Assembly in October of $1785 .^{33}$ The bill prohibited the taking of deer under certain circumstances and ends with the following stricture:

[A]nd, if, within twelve months after the date of the recognizance he shall bear a gun out of his inclosed ground, unless whilst performing military duty, it shall be deemed a breach of the recognizance, and be good cause to bind him a new, and every such bearing of a gun shall be a breach of the new recognizance and cause to bind him again. ${ }^{34}$

Here "bear a gun" is clearly being used in a nonmilitary context, as it exempts military bearing of a gun from the prohibition imposed on those who previously violated the act. (Note, however, that even offenders may still "bear a gun" on their own property.)

Garry Wills dismisses this highly inconvenient bill with some too-fancy footwork: "Not only is the context different from the amendment's, but the 'bearing of a gun' is not the canonical formulation with a plural noun." ${ }^{35}$ As to the first part of this sentence, Wills fails to note that the statute which he claims uses the term in a different context, exempts military duty from the

30. Id. at 194 (citing Garry Wills, To Keep and Bear Arms, N.Y. REV. BOOKS, Sept. 21, 1995, at 64 (hereinafter Wills, To Keep and Bear Ams ] (emphasis added)). For responses to Wills by Sanford Levinson, David C. Williams, Glenn Harlan Reynolds, and John K. Lattimer, and for Wills's reply, see To Keep and Bear Arms: An Exchange, N.Y.REV. Books, Nov. 16, 1995, at 6164.

31. Id. at 149 .

32. See infra notes $34-43$ and accompanying text.

33. Thomas jefferson, A Bill for the Preservation of Deer (Oct. 31, 1785), in 2 THE PAPERS OF Thomas JeffERSON 443, 444 (Julian P. Boyd ad., 1950).

34. Id. (emphasis added).

35. Wills, To Keep and Bear Arms, supro note 30, at 64-65. 
scope of its prohibition, showing that it would otherwise be included in "bearing a gun." In rejecting the relevance of this statute on the ground that the context differs, he also assumes his conclusion-that the Second Amendment was exclusively military-a conclusion based in part on his contention that "bear arms" is exclusively military. But the statute is offered precisely to show that the term "bear arms" had a nonmilitary usage, in this case that of hunting. So the statute undermines Wills's claim that the context of the Second Amendment is indeed different, and his reassertion of the "context" point to refute this inference is a non sequitur.

As for the second part, Wills is echoing a point made earlier in his review that "[o]ne does not 'bear arm.' Latin arma is, etymologically, war 'equipment,' and it has no singular forms." cies of language known to philosophers as a "mass noun." ${ }^{37}$ Mass nouns like "equipment" are useful when you need a term that will describe a class of items without limiting yourself to particular types of the class. Take the word "luggage." You can say "pieces of luggage" or "suitcase" but there is no singular of "luggage" (i.e., you do not say, hand me that "lugg"). A "right to luggage" would not, grammatically, be a right that could only be exercised collectively or en masse. Though ostensibly plural in form, the tern "arms" is functioning here as a mass noun. The Founders would not have wanted to use the plural of "gun," for example, because the tern "arns" also includes edge weapons as well as weapons to be invented in the future. The fact that there is no singular of "arms" tells us exactly nothing about its application. Wills's argument might be dubbed a grammatical fallacy. ${ }^{38}$

Even though Jefferson's bill concerns only one type of arms (guns), it refutes Wills's claim that "[o]ne does not bear arms against a rabbit." However strange it may sound to his ears, it is undeniable that both Jefferson and Madison did not think it odd to say that one does "bear a gun" to hunt deer. ${ }^{4 \theta}$ So do others of their contemporaries, discussed below, whose statements to this effect are dismissed by Wills and by the authors because they do not fit the authors' and Wills's opinion about the historical "context."

\section{Id. at 64 .}

37. The New Oxford English Dictionary defines "mass noun" as "a noun denozing something that canno: be counted (e.g., a substance or quality), in English usually a noun that lacks a plural in ordinary usage and is not used with the indefinite article, e.g., luggage, china, happiness Contrastod with COUNT NOUN." NEW OXFORD ENGLISH DICTIONARY 1051 (2001).

38. Another such grammatical fallacy is the claim that "commerce" in the Commerce Clause had a nansow mearing excluding manufacturing bocause you would not speak of inarufacturing among the several states. But this awkwardness is caused by the meaning of "among the several states" that limits the type of activities to those that could be conducted across state lines. Though it is true that the original meaning of "commerce" did exclude manufacturing, this is established by diract evidence of usage and the grammatical awkwardness of substituting "manufacturing" for "commerce" in the Commerce Clause tells us nothing about its original meaning. Barnett, The Original Meaning of the Commerce Clause, supra note 10, a: 112-13.

39. Wills, To Keep and Bear Arms, supra note 30, at 64.

40. See supra note 34 and accompanying tex: 
The authors (and Wills) fail to discuss the first leamed treatise on the Constitution authored by jurist and law professor St. George Tucker in his annotated edition of Blackstone's Commentaries, published in 1803, and based on lectures that he gave in the 1790s. ${ }^{4 !}$ There, Tucker offers the following example of judicial review under the Necessary and Proper Clause:

If, for example, congress were to pass a law prohibiting any person from bearing arms, as a means of preventing insurrections, the judicial courts, under the construction of the words necessary and proper, here contended for, would be able to pronounce decidedly upon the constitutionality of these means. But if congress may use any means, which they choose to adopt, the provision in the constitution which secures to the people the right of bearing arms, is a mere nullity; and any man imprisoned for bearing arms under such an act, might be without relief; because in that case, no court could have any power to pronounce on the necessity or propriety of the means adopted by congress to carry any specified power into complete effect. ${ }^{42}$

Tucker here is clearly discussing an individual right to keep and bear arms outside of any militia context, and he ignores entirely the preface to the Amendment.

Another important counterexample to their thesis that "bear anns" had an exclusively military meaning, one that the authors do discuss, is the recommendation of the minority report of the Pennsylvania ratification convention that the Constitution be amended to include the following:

That the people have a right to bear arms for the defense of themselves and their own State, or the United States, or for the purpose of killing game; and no law shall be passed for disarning the people or any of them, unless for crimes committed, or real danger of public injury from individuals; and as standing armies in the time of peace are dangerous to liberty, they ought not to be kept up; and that the military shall be kept under strict subordination to and governed by the civil power. $^{43}$

The authors readily concede that this proposal clearly uses "bear arnns" to include both nonmilitary ("defense of themselves," "for the purpose of killing game") and military ("and their own State") contexts, thus

41. The omission is curious as Tucker is discussed in articles cited and criticized by Uviller and Merke!. They would have had to have skipped over this source in one article they discuss to reach the quotation fiom the later ireatise by Joseph Stoly, the treament of which they chose to discuss at some length. See UVILLER \& MERKEL, supra note 1, at 30-31 (discussing the scholariy reatment of a Joseph Story passage by Bamett \& Kates, supra note 23).

42. I ST. GEORGE IUCKER, BLACKSTONE'S COMMENTARIES: WITH NOTES OF REFERENCE TO THE CONSTITUTION AND LAWS OF THE FEDERAL GOVERNMENT OF THE UNITED STATES AND OF TIIE COMMONWEALTH OF VIRGINIA 289 (Augustus M. Kelley ed., 1969) (1803) (emphasis added).

43. Pennsylvania Ratification Convention Minority Proposal (Dec. 12, I787) (emphasis added), reprinted in THE COMPLETE BILL OF RighTS 182 (Neil H. Cogan ed., 1997). 
undercutting the claim that "bear arms" had an exclusively military connotation. But they repeatedly dismiss the minority report as reflecting "marginal voices," "44 "disaffected minority,", and "some radical, libertarian support for an unrestricted right to weapons. ${ }^{\circ 6}$ They claim that the minority report's "view of arms-related rights did not represent majority opinion in Pennsylvania," arms for purposes beyond service in the lawful state militia may have resonated with some groups of anarchic radicals, but that majority sentiment and enlightened reason failed to embrace constitutional claims for such a right in Pennsylvania." 48 They even go so far as to claim that "[ $[$ these supporters of [a] constitutional right to own weapons for private purposes were atypical even within the anti-federalist movement, and they remained insignificant within the nation as a whole." 49 One suspects from their vehement denunciation of these delegates that the authors think this proposal of the Pennsylvania minority hurts their case badly.

But, for all this sound and fury, it is remarkable that the authors offer little, if any, evidence or secondary support for these claims about popular opinion. $^{50}$ Perhaps they base these claims on the fact that this is a recommendation made by a "minority" of delegates to the Pennsylvania convention, but it is well known that several of the earlier constitutional conventions were packed by the comparatively well-organized Federalists. The fact that this particular sentiment was held by a minority of delegates tells us next to nothing about whether it reflects the common view among Pennsylvanians at large. Further, this individualist view of the right to keep and bear anns could easily have reflected the view of the majority of delegates themselves who nevertheless supported ratifying the Constitution without amendments. Indeed, the strategy of ratification conventions proposing amendments to Congress developed later in the ratification process. ${ }^{51}$

44. UVILLER \& MERKEL, supra note 1, at 82.

45. Id. at 83 .

46. Id.

47. $I d$.

48. Id. at 85

49. Id. at 81 ; see also id. at 91 (referring to "the radical fringe"); id. at 100 (referring to "a few radicals outside Congress"); id. at $241 \mathrm{n} .71$ ("[T]hese endorsements almost invainiably issue from the pens of marginal, radical figures who did not represent the mainstream of either federal or antifederal thought.").

50. The only related footnote references in the book are (1) to a Fifth Circuit decision, United States $v$. Emerson, that does not charactenize as radical or minority the listed voices that buttress an individual right to bear arns and (2) to pages of an article by Saul Cornell that contain no claims about majority versus minority sentiments. Id. at $241 \mathrm{n.71}$; see United States v. Emerson, 270 F.3d 203 (5th Cir. 2001); Saul Cornell, Common place or Anachronism: The Standard Model, the Second Amendment, and the Problem of History in Contemporany Constitutional Theory, 16 CONST. COMMENT. 22I, 231-34 (1999) (discussing the constitutional perspectives of the Pennsylvania Antifederalists on the individual right to bear anns).

51. The Pennsylvania convention, the second to ratify the Constitution, did so on December 12 , 1787. 2 DOCUMENTARY HISTORY OF THE CONSTITUIION OF THE UNITED STATES OF AMERICA 27 
Evidence is required to establish the authors' dismissive claims, but none on this point is offered.

When characterizing the Pennsylvania minority report as reflecting the views of wild anarchic deviants, the authors fail to mention the wording of the right-to-arms provision of the Pennsylvania Constitution of 1776: "That the people have a right to bear arms for the defence of themselves and the state ...."52 This right was reaffirmed in the 1790 Constitution in a passage that reads: "That the right of citizens to bear arms, in defence of themselves and the state, shall not be questioned." 53 In addition to using the same phraseology as the Pennsylvania minority, neither provision in these enacted state constitutions even mentions the militia. So there is good reason to believe that the Pennsylvania dissenters were merely elaborating the individual, nonmilitia-conditioned right to bear arms already included in their state constitution. In fairzess then, the Pennsylvania dissenters can hardly be "discount[ed] ... as the rambling catch-all compendium of one man bent on scuttling ratification" 54 without some evidence that this was so.

Nor was the Pennsylvania minority alone in attempting to amend the Constitution to protect an individual right to arms not conditioned on militia service. Included in the minority recommendation of the Massachusetts convention was this proposed amendment:

[The] Constitution be never construed... to prevent the people of the United States, who are peaceable citizens, from keeping their own arms; or to raise standing annies, unless when necessary for the defence of the United States, or of some one or more of them; or to prevent the people from petitioning, in a peaceable and orderly manner, the federal legislature, for a redress of grievances; or to subject the people to unreasonable searches and seizures of their persons, papers or possessions. ${ }^{55}$

(1894). The furst state convention to append proposed amendments was Massachusetts - - the sixth state to ratify-which voted for ratification on February 6, 1788. Id. at 93-96. After Massachusetts, all of the remaining seven states except Matyland proposed amendments to the Constitution along with their vote to tatify. Id. at 97 . These proposals can also be accessed online from the Avalon Project at Yale Law School, at http:/www.yale.o3u/lawweb/avalon/88th.htn (click on "Ratification of the Const:tution" for an indi vidual state) (last visited Oct. 17, 2004).

52. PA. CONST. of 1776 , ch. l, art. XIIl, reprinted in THE COMPLETE BILL Of RIGHTS, supra note 43 , at 184 . The Vernont Constitution of 1777 contains identical language. VT. CONST. of 1777, ch. I, an. XV, reprinted in THE COMPLEIE BILL OF RIGHTS, supra note 43, at 184.

53. PA. CONST. of 1790, art. IX, §21 (emphasis added), reprinted in THE COMPLETE BILl of RIGHTS, supra note 43 , at 184.

54. UVILLER \& MERKEL, supra note 1 , at 270 n.90.

55. Massachusetts Ratification Convention Minority Proposal (Feb. 6, 1788) (emphasis added), reprinted in THE COMPLETE BILL OF RIGHTS, supro note 43, at 181. This recommendation is in contrast with the Massachusetts state constitution that protected only the right to bear arms "for the common defence." MASS. CONST. of 1780, pt. 1, art. XVH, reprinted in TME COMPLETE BiLL OF RIGHTS, supra note 43, at 183. 
As in Pennsylvania, this proposal does not explicitly mention the militia. The right to keep arms appears among a list of purely individual rights, none of which are in any way conditioned upon service in the militia.

In addition, the New Hampshire ratification convention officially proposed that the Constitution be amended to read that "Congress shall never disarn any Citizen unless such as are or have been in Actual Rebellion." 56 Uviller and Merkel grudgingly concede that this proposal "might support the argument that a private right to gun possession is protected." be noted that none of the other right-to-arms proposals made by New York, North Carolina, Virginia, or Rhode Island were expressly limited to "the common defence" or "the defence of the state," 58 though, as the authors note, the Massachusetts Bill of Rights was qualified in this way. ${ }^{59}$

Uviller and Merkel should be estopped from responding that the language in the Pennsylvania and Vermont constitutions does not reflect an individual right exercisable both within and outside of militia service, for their interpretation of these passages is inconsistent with such an argument. ${ }^{60}$ When discussing the later Kentucky case of Bliss v. Commonwealth, in which the court interprets the very same language in the Kentucky Constitution as protecting an individual right, ${ }^{61}$ the authors readily concede that it does indeed have this broader meaning. ${ }^{62}$ They respond by distinguishing the language on the ground that this wording differs from that of the Second Amendment. ${ }^{63}$ By striking down a law banning concealed weapons, they note that "the [Kentucky] Court of Appeals acknowledged a

56. New Hampshire Ratification Convention Repost (June 21, 1788) (emphasis added), reprinted in THE COMPLETE BILL OF RIGHTS, supra note 43, at 181. The authors claim, again without evidence, that this proposal "sought to push the republic further than any of the other states desired to go." UVILLER \& MERKEL, supra note 1 , at 82.

57. UVILLER \& MERKEL, supra note 1, at 82 (emphasis added). Even a single example of a patently individual right to bear arms rebuts a charge commonly made by collective-right proponents, and now by militia-conditioned-individual-right proponents, that the unconditionedindividual-rights fomulation is a pure invention of modem gun rights scholars with no basis in history.

58. New York Proposal (July 26, 1788), reprinted in THE COMPLETE BILL OF RJGHTS, supra note 43, at 181 -82; North Carolina Proposal (Aug. 1, 1788), reprinted in THE COMPLETE BILL OF RIGHTS, supro note 43, at 182; Virginia Proposal (Jun. 27, 1788), reprinted in THE COMPLETE BILL OF RIGHTS, supra note 43, at 182-83; Rhode Island Proposal (May 20, 1790), reprinted in THE COMPLETE BILL OF RiGHTS, supro note 43, at 182.

59. UVILLER \& MERKEI, supranote 1 , at 82.

60. Others not so constrained may contend that "the defence of themselves" was still a collective notion referring to "the community," and such defense was to be done entirely withm the context of the militia. I address this claim-which is not made by Uviller and Merkel -in subpast II(D). See infro notes 115-39139 and accompanying text.

61. 12 Ky. (2 Lin.) 90,90 (1822).

62. UVIILER \& MERKEL, supra note 1 , at 27-28

63. Id. at 28 . 
private, state constitutional right for purposes having nothing to do with militia service."

The authors also dismiss the 1846 Georgia case of Nunn v. State, in which the state judge found a law banning certain pistols to be unconstitutional under both the Georgia constitution and the Second Amendment. ${ }^{65}$ Here the authors criticize the judge for not considering himself sufficiently bound by the "revered" John Marshall's earlier opinion in Barron v. Baltimore in which the Court held that the Bill of Rights applied only to the federal government. ${ }^{66}$ "[F] $]$ or those who seek a coherent doctrine," they write, "Nunn v. Georgia [sic] is a case of no importance whatever." ${ }^{67}$ But coherent doctrine is not why we look to Nunn. Rather Nunn is significant because it is inconsistent with the claim that the right to keep and bear arns existed only in the context of militia service.

Moreover, in their dismissal of Nunn, Uviller and Merkel fail to appreciate that many people then viewed the Bill of Rights, at least in part, as declaratory of preexisting rights and therefore as good authority to anyone, including a state court, wying to ascertain what the fundamental rights of persons might be. ${ }^{68}$ Strictly speaking, Barron merely deprives the rights specified in the Bill of Rights of federal protection as against state governments. The Court does not hold that these rights are inapplicable to the states, should state courts decide to apply them. However this issue is decided, the opinion in Nunn still stands as an example of the right to bear anns being interpreted as an individual right outside the military context.

Surprisingly, nowhere in their book do the authors discuss how the right to keep and bear anns related to the natural right of self defense, though the wording of the Pennsylvania Constitution and other statements invokes a right of "def ence." 69 Instead, the authors claim that the right to anns "did not readily lend itself to Locke's rational and enlightened discourse about the nature of man and the entitlements appurtenant thereto."70 Scholarly literature is replete with observation that the right to keep and bear anns was

64. Id. The authors then gratuitously observe that subsequent Kentucky constitutions expressly "allowed the legislature to pass gun contol laws." Id. This futher modification of the text, howcver, supports the view that the unmoditied language protccted an individual-right-free-ofmilitia connotation.

65. 1 Ga. 243 (1846). The authors cite this case as Nunn v. Georgia. UVILLER \& MERKEL, supranote 1 , at 30 .

66. 32 U.S. 243, 247-5 I (1833); UVILLER \& MERKEL, supra note 1, at 29-30.

67. UVILLER \& MERKEL, supra note 1, at 30.

68. See AKHIL REED AMAR, THE BILL OF RIGHTS: CREATION AND RECONSTRUCTION 147-56 (1998) (describing "thc declaratory theory" of the Bill of Rights).

69. See, e.g., PA. CONST. of 1790, art. IX, § 21, reprinted in THE COMPLETE Blid OF RIGHTS, supra note 43 , at $! 84$.

70. UVILLER \& MER KEL, supra note I, at 164. 
viewed as an extension of the fundamental right of self defense, ${ }^{71}$ but the authors cursorily dismiss this notion in their book. ${ }^{72}$

The authors attempt to mitigate Nunn $v$. State by discussing the 1840 Tennessee case of Aymette v. State. ${ }^{73}$ In Aymette, the court upheld a ban on the wearing of a concealed bowie-knife, reasoning that "[t]hese weapons would be useless in war. They could not be employed advantageously in the common defence of the citizens. The right to keep and bear them is not, therefore, secured by the constiturion."74 Uviller and Merkel claim that the state constitutional provision in question was "similar in form and words to the federal Second Amendment." 75 But unlike the Second Amendment (and the other proposed amendments and state right-to-arms provisions discussed above), the Tennessee constitutional provision qualified the right to bear arms by the phrase "for their common defence,"," and the court places great stress on this language in the passage quoted by Uviller and Merkel. ${ }^{77}$ As the authors acknowledge elsewhere ${ }^{78}$ this language suggests a more military or mutual defense meaning.

In contrast to the language of the Tennessee constitution, however, the U.S. Senate rejected a proposal to add the qualifier "for the common defence" to the language of the Second Amendment. ${ }^{79}$ While the authors dismiss the significance of the Senate's refisal on the ground that this qualifying language was redundant, ${ }^{80}$ their assertion requires independent proof that the unqualified right is already limited to uses of arms for the common defense and does not also include the use of arms by the people in defense of themselves, as several state constitutions specified. In other words, only if you assume that you have established the meaning of the right to keep and

71. See generally Anthony J. Dennis, Clearing the Smoke from the Right to Bear Arms and the Second Amendinent, 29 AKRON L. REV. 57 (1995); David B. Kopel, The Self-Defense Cases, 27 AM. J. CRIM. L. 293 (2000)

72. UVILLER \& MERKEL, supra note l, at 366-67.

73. 2 I Tenn. (2 Hum.) I52 (1840).

74. Id at 156. The authors are wrong to claim that individual rights scholars are guilky of "Ii]gnoring the case from Tennessee." UVILLER \& MERKEL, supra note 1, at 27. It is widely discussed in the Second Amendment literature. E.g., STEPHEN P. HALBROOK, THAT EVERY MAN BE ARIMED: THE EVOLUITON OF A CONSTITUTIONAL, RIGHT 94 (1984). By contrast, Halbrook notes an earlier 1833 case, overlooked by the authors, in which the Tennessee court offered a broader meaning of the right-to-arms provision in Tennessee's constitution: "By this clause of the constitution, an express power is given and secured to all the free citizens of the State to keep and bear arms for their defense, without any qualification whatever as to their kind or nature." Simpson v. State, I3 Tenn. (5 Yer.) 356, 360 (1833) (emphasis added), quoted in HALBROOK, supra, aई 94.

75. UVILLER \& MERKEL, supra note 1 , at 27.

76. TENN. CONST. of 1836, art. I, § 26, quoted in Aymette v. State, 2I Tenn. (2 Hum.) I54, 158 (1840).

77. UVILLER \& MERKEL, supra note I, at 27.

78. Id. at 104.

79. Id. at 103.

80. Id. at 104 (arguing that "invocation of ams bearing in the militia already clearly proclaimed the puipose of common defense to eighteenth-century cars"). But the Second Amendment does not refer to "arms bearing in the milit ia." 
bear arms can you contend that this additional language was superfluous. Equally if not more plausible is the inference that the qualifying language might well have been rejected because it unduly narrowed the scope of the right. In the absence of any recorded debate, we just do not know.

\section{B. Evidence That the Right "to Keep" Arms is Not Military}

To determine original meaning, as opposed to original intent, the cryptic and unreported Senate deliberations are far less important than the existence of state constitutional right-to-arms guarantees that included the broader "defence of themselves" language. A member of the public in 179! reading the Second Amendment would likely not assume that the unqualified right in the Amendment actually meant something narrower than the broad right to anns for both personal and collective self defense that was already protected by some state constitutions.

Take, for example, the reaction to Madison's proposed amendments by Samuel Nasson, an Antifederalist representative to the Massachusetts ratification convention held the previous year. In a letter to George Thatcher, a Federalist congressman from Massachusetts, Nasson wrote:

I find that Ammendments [sic] are once again on the Carpet. I hope that such may take place as will be for the Best Interest of the whole. A Bill of rights well secured that we the people may know how far we may Proceade in Every Department then their will be no Dispute Between the poople and rulers in that may be secured the right to keep anns for Common and Extraordinary Occations such as to secure ourselves against the wild Beast and also to amuse us by fowling and for our Defence against a Conunon Enemy.... ${ }^{8 t}$

Nasson then goes on to extol the virtue of popular resistance to a "foreign foe" and condemn standing annies in times of peace. ${ }^{82}$ Notwithstanding his concem for the common def ense, Nasson nevertheless reads the right to keep arms in the Second Amendment as also a personal one, unconnected with militia service. ${ }^{83}$ Note also, that Nasson uses "arms" for hunting, in contrast with Garry Wills's assertions. ${ }^{84}$

This quote goes unmentioned by Uviller and Merkel, though it appears in the Fifth Circuit's opinion in United States v. Emerson, ${ }^{85}$ an opinion that they much discuss and disparage. ${ }^{86}$ Instead of letting readers make up their own minds about such contemporary statements, this highly inconvenient

81. Letter from Samuel Nasson to George Thatcher (July 9, 1789), in CREATING THE BiLl OF RIGHTS: THE DOCUMENTARY RECORD FROM THE FIRST FEDERAL CONGRESS 260-61 (Helen E. Veit et al. eds., 1991) (emphasis added).

82. Id.

83. Id.

84. Wills, To Keep and Bear Arms, supra note 30, at 64.

85. 270 F.3d 203, 253 (5th Cir. 2001).

86. UVILLER \& MERKEL, supra note !, at 220-24. 
direct evidence of original meaning is dismissed by the authors in a single conclusory sentence: "Contrary to many commentators and to our own interpretation, the court finds 'numerous instances' where the words were employed to connote private carrying for private purposes. Accordingly, they conclude that the term ref ers to carrying or wearing arms generally."

An earlier letter from Massachusetts historian and pastor Jeremy Belknap to Federalist Paine Wingate, written in May 1789, evidences that Nasson was not alone in this individualist reading of the right to arms. ${ }^{88}$ Belknap writes of his pleasure with Samuel Adams's investiture speech as lieutenant governor in which Adams affirmed that:

"[T]he people may enjoy well grounded confidence that their personal \& domestic rights are secure." This is the same Language or nearly the same which he used in the [Massachusetts ratification] Convention when he moved for an addition to the proposed Amendments-by inserting a clause to provide for the Liberty of the press- the right to keep amns-Protection from seizure of person \& property \& the Rights of Conscience. ${ }^{89}$

As it turned out, none of these "personal and domestic" rights were included among the amendments proposed by the Massachusetts convention. $^{90}$ Would anyone, however, fairly conclude from this omission that the liberty of the press or the right of conscience was supported only by a minority or radical fringe of the population of Massachusetts? More importantly, these two contemporary letters join the ranks of other direct statements about the public meaning of the Second Amendment and the right to keep and bear arns, indicating that the Second Amendment right protected a personal, individual right like the other rights in the Bill of Rights.

These statements by Nasson and Belknap, along with the previously quoted proposal from the Massachusetts minority, highlight a single fact overlooked by the authors and by others who now base their historical argument on the supposedly military meaning of "bear arms": The Second Amendment also protects the right to keep arms. No evidence is presented by the authors to show that "keep" was a military term at all, much less exclusively so." These references to a personal, individual right "to keep arms" are significant, therefore, because even if "bear arnns" did have an exclusively military connotation, the individual and nonmilitary right to "keep" arms still colors the meaning of the Second Amendment as a whole, giving it a nonmilitary meaning as well.

87. Id. at 222.

88. Letter from Jeremy Belknap to Paine Wingate (May 29, 1789), in CREATTNG THE BILL OF RIGHTS, supra note 81 , at $241,241$.

89. Id. (quoting Samuel Adams's investinure speech as lieurenant governor).

90. Amendments Proposed by the Massachusetts Convention (Feb. 6, 1788), in CREA TING THE BILLOF RIGHTS, supra note 81, at I4, 14-15.

91. See UVILLER \& MERKEL, supra note 1 , at 149. 
Perhaps because the Second Amendment literature had not previously discussed the Nasson and Belknap statements, Wills fails to consider them in his exposition on the meaning of "to keep." 92 The best counterexample that he can produce is a statement in which John Trenchard "advised that 'a competent number of them [firelocks] be kept in every parish for the young men to exercise with on holidays.",93 That "kept" can be used in a military context, however, does not give the word itself a military connotation. "Truck" can be used in a military context too, but that does not make the word itself military, much less exclusively military. That arms can be "kept" in an armory, as of course they can, does not mean that they cannot also be "kept" at home. 94

Wills concludes: "To separate one tern from this context and treat it as specifying a different right (of home possession) is to impart into the language something foreign to each tern in itself, to the conjunction of terns, and to the entire context of Madison's sentence." 95 But given his lack of evidence, Wills's argument concerning "to keep" must really boil down to his tenuous claim that "bear arns" is exclusively military and therefore "to keep" must be military when conjoined with it. With Nasson, Belknap, and the authors of the Massachusetts minority report, however, we have actual members of the public at the founding ref erencing the right to keep arms and describing it as a nonmilitary right. Appeals to "context" cannot silence

92. It is typical in this debate for the individual-rights scholars to produce direct evidence of usage, which their opponents then attempt to shoot down, usually by asserting some larger "context," rather than producing new direct evidence of their own.

93. Wills, To Keep and Bear Ams, supra note 30, at 67 (quoting JOHN TRENCHARD, AN ARGUMENT, SHEWING, THAT a STANDING ARMY IS INCONSISTENT WITH A FREE GOVERNMENT AND ABSOLUTELY DESTRUCTIVE TO THE CONST্যUUTON OF THE ENGLISH MONARCHY 21 (1697)) (alteration in Wills's articie) (emphasis added by Wills). Wiils also offers a quote from Federalist 25 in which Alexander Hamiiton records that "the objoction to standing annies was to keeping them up in a season of tranquility." Id. at 67 n.30 (quoting THE FEDERADIST NO. 25, at 160 (Alexander Hamilton) (jacob E. Cooke ed., [96I)). Wills notes that "[a]s an English noun, 'keep' meant the permanently holdable part of a castie...." Id. at $67 \mathrm{n} .34$. Fair-minded rcaders can decide for themselves if Wills is being sensitive here to "context." and whether these uses of "keep" in any way detract from the significance of the use of "kcep anns" by Nasson and Belknap. Or might Wills himself be gailty of the same foible that he accuses individual-rights scholars of manif esting- "seeking out eveiy odd, loose, or idiosyncratic" use of a tern "in defiance of the solid body of central reference," id. at 64 , or of what he dubs thc "throw-in-the-kitchen-sink approach?" Id. at 65 .

94. It is perhaps usefial to remember that, in 1995, Wills was writing before gun rights opponents had made the transition from the "collective right"-of-states interpretation of the Second Amendment to the new mijitia-conditioned-individuai-right theory. Hence, he still is claiming that the original meaning of the Second Amendment in the Bill of Rights was to protect the rights of states to have a militia - the view now rejected by writers such as Uvilier and Merkel. UViLLER \& MERKEL, supra note I, at 12. Additional evidence is needed to fully refute this claim. For a surnmary, see United States v. Emerson, 270 F.3d 203, 236-60 (5th Cir. 2001). Wills's work is worth mentioning, however, because writers like Uviller and Merkel still rely heavily on his New York Review of Books essay claiming that "bear arms" was an exclusively military term. UViLLER \&MERKEL, supra note 1, at 27, 104-05, 194, 296-97.

95. Wills, To Keep and Bear Arms, supra note 30, at 68. 
these contemporary statements. If anything, con joining the right to bear arms with the nonmilitary right to keep arms renders them both nonmilitary in this context, but there is no reason to insist on so narrow a definition.

These statements-like others relied upon by individual-rights scholars that I do not reiterate here ${ }^{96}$ are direct evidence of what the public thought the Second Amendment phrase "the right to keep and bear anns" meant. Unlike the authorities relied upon by Uviller and Merkel (or Wills), they are not statements merely evincing a concern for the militia, from which we are supposed to circumstantially infer what the "right to keep and bear arms" might have meant. These statements evidence what the specific words of the Second Amendment objectively manif ested to real people. The dirty little secret of this long-running debate is that only one side has produced any concrete examples of actual statements from the founding era expressing that side's interpretation of the right to keep and bear arms and the Second Amendment.

\section{Evidence That to "Bear Arms" Meant to Carry Arms}

Several times the authors assert, once again without evidence, that the term "bear arms" was chosen because it did not connote the mere carrying of guns. "In late-eighteenth-century parlance, bearing arms was a term of art with an obvious military and legal connotation. 'Carrying a gun' lacks the implication of bearing arms and, of course, the Constitution nowhere mentions a 'right to carry a gun." 97 The 1785 edition of Samuel Johnson's $A$ Dictionary of the English Language repeatedly defines "bear" as "carry." 98 After describing "bear" as a "word used with such latitude, that it is not easily explained," the dictionary lists its first meaning as "To carry as a burden," followed immediately by "To convey or carry," "To carry as a mark of authority," "To carry as a mark of distinction," "To carry as in show," "To

96. For a useful compendium of examples, see Emerson, 27 F.3d at 236-59. Those who oppose the individual-rights interpretation love to deride the reiteration of the same examples, as though examples of usage wear out from ovenuse. See, e.g., Wills, To Keep and Bear Arms, supra note 30, at 65 (noting that "Standard Modelers" refer "again and again" to the Pennsylvania ratifying convention's minority vote to place killing game among the objects of a right to bcar arms). In contrast, they offer no examples of founding-era views regarding the Second Amendment, or the right to keep and bear anns, that conespond to the view that they claim everyone held. E.g., UVILLER \& MERKEL, supra note 1, at !09 ("To the ratif"ers, the right to keep and bear arms was inextricably and exclusively bound to the maintenance of a militia ...."). Instead, they use "context" to explain away and trump the contrary evidence. When it comes to historical evidence, however, you cannet beat something with nothing.

97. UVILLER \& MERKEL, supra note 1, at 26-27; see also id. at 149 ("The right to arms is declared by the verbs, 'keep and bear,' a phrase carefully selected in preference to alternatives such as 'have,' 'own,' 'carsy,' or 'possess."'). The authors offer no independent evidence as to the "care" that went into this verbal choice. See id. The argument that the phrase "keep and bear" must have been carefully chosen instead of these other words that connote a different meaning assamcs a fact that must be shown: that these other words would indeed have connoted a different meaning.

98. I SAMUEL JOHNSON, A DictionaRY OF THE ENGLISH LANGUAGE (not paginated) (photo. seprint 1990) ( 1755$)$. 
carry as in trust," and "To carry in the mind, as love, hate." So "carry" seems to be the most prevalent synonym of "bear." The same is true for the first edition of Webster's dictionary, which defined "bear" as "[ $t] 0$ carry" and which mentions "to carry" nine times in discussing the term's derivation from other languages. ${ }^{100}$ So far as Johnson and Webster are concerned, "to bear" simply means to carry.

This usage is borne out in the context of the Second Amendment by the Supreme Court's earliest known reference to the right to arms. This reference goes unmentioned by the authors (and Wills), though Uviller and Merkel purport to comprehensively discuss the few times that the Supreme Court has discussed the Second Amendment, including even a television interview with Chief Justice Warren Burger. ${ }^{101}$ In his infamous opinion in Dred Scott $v$. Sandford, Chief Justice Taney denies that blacks could have been considered citizens of the United States for, if that were the case, then blacks would enjoy along with whites "the full liberty of speech ... and to keep and carry arms wherever they went." 102

In this passage, Justice Taney uses "carry" as a substitute or synonym for "bear" and implies that the right protected by the Socond Amendment is to carry weapons wherever one travels, a right completely unconnected with active militia service. ${ }^{103}$ Taney groups the right to keep and bear arms in the Second Amendment with the equally nonmilitary liberty of speech protected by the First Amendment. ${ }^{104}$ And he obviously thinks that his readers would share his interpretation of the Second Amendment, or his reductio ad absurdum for black citizenship would fail.

The authors cannot have omitted Taney's opinion because of its late date or racist reasoning and outcome because they rely on the nearly-as-vile ruling in United States v. Cruikshank, an even later opinion in which the Supreme Court frees some members of the $\mathrm{Ku}$ Klux Klan who were convicted of violating the civil rights of blacks in Louisiana by torturing and murdering them. ${ }^{105}$ According to the reasoning of the Court in Cruikshank, cited approvingly by the authors, ${ }^{106}$ the defendants could not have been guilty of violating the victims' rights under color of state law because the entire Bill

99. Id.

100. NOAH WeBSTER, AN AMERICAN Dictionary of THE ENGLiSH LANGUAGE (ist ed. 1828) (not paginated) (listing "To carry" as the second definition out of twenty; the first definition-"To support; to sustain"-is less relevant in the context of amns).

101. UVILLER \& MERKEL, supra note 1, at 13.

102. 60 U.S. 393,417 (1856).

103. See id.

104. See id.

105. 92 U.S. 542, 559 (1875).

106. UVILLER \& MERKEL, supra note 1, at 14. 
of Rights, including the rights of assembly and to keep and bear arms, applies only to federal, and not state, exercises of power. ${ }^{107}$

Although today we protect such liberties (a historically and incompletely) by "incorporating" them into the Due Process Clause, the protection of the right to arms against infingement by the states, as I discuss below in Part IV, is more properly included within the original meaning of the Privileges or Immunities Clause of the Fourteenth Amendment. ${ }^{108}$ Clearly, however, if the later doctrine of incorporation properly applies to the right of assembly, it can just as easily apply to the right to arrns, Cruikshank notwithstanding.

Some might object to the relevance of all the nineteenth-century cases that I have discussed for establishing original meaning of an amendment enacted in 1791, and 1 sympathize with the objection. The farther in time that one gets fiom promulgation, the less germane is the evidence of public meaning. I offer these cases because nineteenth-century cases are discussed at length by the authors in their opening chapter ${ }^{109}$ and because they concede that these cases interpreting the language "in defence of themselves and the state" represent the antithesis of their view. ${ }^{110}$ This in tum is relevant to the meaning of the same language used at the founding in right-to-arms provisions in the state constitutions discussed above. "II

Also, more recent cases are usefill to establish the late development of a collective or states-rights view of thc amendment - a view unknown at the founding and correctly rejected by the authors. ${ }^{112}$ Finally, Taney's opinion in Dred Scott refutes the authors' suggestion that the Supreme Court has never considered the Second Amendment to protect an individual right unconditioned on militia service. ${ }^{113}$ ln this, its earliest known mention of the Amendment, the Court clearly did.

\section{Was "defence of themselves" Also Exclusively Military?}

Before moving on to the next problem with Uviller and Merkel's originalist argument, let me briefly consider a different militia-conditioned interpretation of "for the defence of themselves and the state" that they do not offer. As we just saw, Uviller and Merkel concede that the wording of the Pennsylvania minority report included a personal right to bear arms

107. Cruikshank, 92 U.S. at 552 . The authors do not inform the reader that the Cruikshank court found that the right of assembly also does not apply to the states via the Fourteenth Amendment. UVILLER \& MERKEL, supra note l, at 14.

108. See infra notes $160-73$ and accompanying text.

109. UVILLER \& MERKEL, supra note 1, at 9-36.

110. Id. at 12-13.

111. Se e supra notes $52,61-64,76$, and accompanying text.

112. UVILER \& MERKEL, supra note 1 , at 179.

113. Id at 13 . 
outside the militia context. ${ }^{114}$ That is why they go to such lengths to marginalize these speakers. Others, however, might claim that the phrase "for the defence of themselves" was the equivalent of "for the defence of the community," a right that also was to be exercised solely in the context of the militia.

Here is a brief list of the problems with that claim:

(I) First, and most importantly, I am aware of no direct evidence of anyone at the time of the founding asserting that "in defence of themselves" means "for the def ence of the community."

(2) As a textual matter, "in defence of themselves" seems most obviously to be simply the plural of the personal right of self defense, a usage that was appropriate given that the subject of the right is the plural tern "the people." In other words, if the drafters wanted to use the tern "the people" as they had in other amendments, and "the people" is the plural of individual person, how else would the right to bear arms for personal self defense be protected besides making the second term "themselves"? A drafter would not write "himselves" or "him or herselves."

(3) Indeed, this same grammatical choice is made in the Fourth Amendment, which refers to the "right of the people to be secure in their persons, houses, papers, and effects ...." used as the plural of individual person, as reflected in the use of the word "their"- just like the use of "themselves" in state constitutions. Similarly, the English Bill of Rights refers to the right of individual protestant "Subjects" to "have Arms for their Defence."116 There is no difference in meaning between "their defence" and "in defence of themselves."

(4) It is true that the founders used "no person" and "any person" in the Fifth Amendment to refer to individuals, ${ }^{117}$ but this is a grammatical consequence of shifting from affirming that everyone has a particular right to a claim about particular individuals not being denied a right. In the absence of direct and compelling historical evidence to the contrary, nothing in the public meaning would turn on this grammatical flip between the Fourth Amendment, on the one hand, and the First, Second, and Fifih Amendments on the other.

(5) Consider this language from the very same 1776 Pennsylvania Declaration of Rights in which the "in defence of themselves" language appears:

114. S'ee discussion supra subpart II(A).

115. U.S. CONST. amend. IV (emphasis added). To forestall fiuture debate on this point, "persons" in this passage refers to their bodies as distinct from their possessions.

116. Bill of Rights, 1688, 1 W. \& M. ch. 2, \& 1 (Eng.) (emphasis added); sae JOYCE LEE MALCOI.M, TO KEEP ANID BEAR ARMS: THE ORIGIN OF AN ANGLO-AMERICAN RIGHT 119 (1994) (describing the legislative history of this formulation, which lacked any militia preface or condition).

117. U.S. CONST. amend. V. 
[T]he people have a right to hold themselves, their houses, papers, and possessions free from search or seizure; and therefore warrants without oaths or affirmations first made, affording a sufficient foundation for them, and whereby any officer or messenger may be commanded or required to search suspected places, or to seize any person or persons, his or their property, not particularly described, are contrary to that right, and ought not to be granted. ${ }^{118}$

Did the use of the tern "themselves" imply that the reference here is to "the community" rather than to individual rights? Hardly. The last portion of this statute refiztes any such suggestion. Nearly identical language appears in the 1777 Vermont Constitution. ${ }^{119}$ Other state constitutional protections from unreasonable searches refer to "every subject" with no apparent difference in meaning. ${ }^{120}$ Or consider this passage from the 1780 Massachusetts Constitution: "that the judges of the supreme judicial court should hold their offices as long as they behave themselves well; and that they should have honorable salaries ascertained and established by standing laws. ${ }^{\text {pi21 }}$

(6) As 1 have already discussed, language expressing "in defence of the community" was readily available and in use in, for example, the Massachusetts Constitution, which referred to "a right to keep and bear arms for the common defense"122 -qualifying language that was proposed and rejected in the Senate as an amendment to the Second Amendment. ${ }^{123}$

(7) Finally, this interpretation of "in defence of themselves" leads to a bizarre interpretation of the Pennsylvania minority report itself that Uviller and Merkel, and others, claim to be a pure (and radical, exceptional, and rejected) statement of individual rights. By this interpretation, even the Pennsylvania dissenters did not seek to protect an individual right of self defense! We would be asked to believe that they sought instead to protect the right to defend the community ("in defence of themselves"), the right to defend the state ("and their own state"- notice the use of the word "their," by the way, as in the Fourth Amendment), and the right to kill game, but not the right to anns for personal self defense. This interpretation would not

118. PA. CONST. of 1776 , ch. 1 , art. $X$ (emphasis added), reprinted in THE COMPLETE Bill of RighrS, supra note 43, at 235.

119. VT. CONST. of 1777 , ch. 1, art. 11 ("That the People have a Right to hold themselves, their Houses, Papers and Possessions free from Search or Seizure....") (emphasis added), reprinted in THE COMPLETE BILL OF RIGHTS, supra note 43, at 235.

120. E.g., MASS. CONST. of 1780 , pt. 1, art. X111, reprinted in THE COMPLETE BiLL OF RIGHTS, supra note 43 , at 234 ; N.H. CONST. of 1783, art. XXII, reprinted in THE COMPLETE BILL OF RIGHIS, szpra note 43, at 234.

121. MASS. CONST. of 1780, art. XXIX (emphasis added), reprinted in THE COMPLETE BILL OF RICHTS, supra note 43, at 234.

122. See supra note 59 and accompanying text.

123. UVILLER \& MERKEL, supra note 1, at 103; see also supra notes $79-80$ and accompanying text. 
only be bizarre, it would contradict Uviller and Merkel's repeated aspersion that the Pennsylvania dissenters were weird radicals and anarchists because they asserted an individual right to keep and bear arms. ${ }^{124}$

\section{E. Evidence of Congressional Usage}

By the end of the book, the authors get a little carried away and assert that "[ $[$ ]o the ratifiers, bearing arms unequivocally meant rendering military service." 125 As we have seen, the examples that they discuss and others that they omit include numerous uses of the term "bear" outside the military context. With one exception, no quantitative evidence is presented here to show that these uses were aberrant. ${ }^{126}$ The exception is found in a footnote, quoting an article by David Yassky in which he reports "searching a Library of Congress database containing all official records of debates in the Continental and U.S. Congresses between 1774 and 1821" and finding that "the phrase had an unambiguously military meaning." "27 Yassky's quantitative survey is highly relevant to the issue of whether the original public meaning of "bear arms" included a military connotation. It establishes this uncontroverted claim beyond any doubt. But as proof that the term had an exclusively military connotation - a much harder claim to establish-it is far from dispositive. The problem is to establish the relevant baseline in the database that Yassky used.

My own search of this database generally confinns that the discussions in which "bear arms" appears (not including references to the Second Amendment) in the period searched by Professor Yassky do indeed concern only military matters. ${ }^{128}$ But this cannot establish, as Yassky asserts, that during this period "the phrase [had] an unambiguously military meaning." 129

\section{Id. at 83 .}

125. Id. at 194 .

126. By quantitative, 1 mean a systematic survey of a database from which conclusions about nonnal and aberrational usage can be drawn. This is not to diminish the type of evidence on which the authors rely. Onen, such statements are all that is available and 1 have relied upon such evidence myself. See supra note 10 (referring to my reliance on stements of various participants in the historical period to detenn une the meaning of the Necessary and Proper Clause). In the absence of quantitative evidence, however, assertions that a particular view was "insignificant" or "radical" or a "minority" view-much less "the rambling catch-all compendium of one man bent on scuttling ratification"-are diff̌icult to establish. UViLIER \& MERKEL, supra note 1, at 81-83, 270 n.90. With respect to the right to keep and bear arms, the situation is worse, as many examples of contemporaries who viewed the right as personal and individual have been produced, while we have no example of a single person who stated that the Second Amendment meant what Uviller and Merkel clai $m$ that everyone but a few radicals thought it meant.

127. David Yassky, The Second Amendment: Structure, History, and Constitutional Change, 99 MiCH. L. REV. 588, 618 (2000), quoted in UVILLER \& MERKEL, supra note 1, at $296 \mathrm{n} .7$.

128. I used the same database as did Yassky, although the years covered by the database seem to have expanded since his search. A Century of Lawmaking for a New Nation: U.S. Congressional Documents and Debates, 1774-1875, at http://memory.loc.gov/ammem/amlaw/lawhome.hm! (last visited Nov. 2003).

129. Yassky, supranote 127 , at618. 
Why not? Because if only military matters were under discussion when arms were mentioned in Congress during this period, then it follows from this fact-and not from any exclusive meaning of the phrase "bear arms"- that all uses of the phrase "bear anns" during this period in this database would necessarily be military.

To test this proposition, I searched for phrases that Uviller and Merkel might concede have nonmilitary connotations, like "carry arms," "possess anns," and "have arms" and found just one nonmilitary result." ${ }^{130}$ Significantly, I also found no references at all in this database to "keep arms," other than one (garbled) reference to the Second Amendment. ${ }^{131}$ This finding further suggests both (1) that the discussions involving "arns" in this database during this period were exclusively about military matters, such that we would expect "bear arns" to be used only in its military sense, and (2) that "keep anns" did not have a commonly employed military connotation. ${ }^{132}$

Prof essor Yassky's findings should not be surprising. Given the narrowly interpreted powers of Congress during the era that he surveyed, 17741821 , it is hardly unexpected that congressional debates would be discussing arms only in a military context. Congress had neither the inclination nor the power to propose laws that would have affected the personal right to keep or bear arms outside the militia context. Besides, it was constitutionally barred from doing so by the Second Amendment.

Furthermore, since Professor Yassky did his search, the Library of Congress extended its database to the year 1875, covering the tumultuous years before, during, and after the Civil War, when the personal, nonmilitary rights of blacks and others to keep and bear arms were perceived as threatened from a variety of sources. Sure enough, four examples of the word "bear arms" from this era appear to refer to a personal right outside the context of the militia. ${ }^{133}$ Each of the following examples substantiates the proposition that, when Congress was discussing nonmilitary matters that

130. "Is it possible, he asked, that an anny could be raised for the pumpose of enslaving thernselves and their brethren? or, if raised, whether they could subdue a nation of freemen, who know how to prize liberty, and who have arms in their hands?" 2 JONATIiAN ELLIOT, THE DEBATES IN THE SEVERAL STATE CONVENTIONS ON THE ADOPTION OF THE FEDERAL CONSTIIUT ION, AS RECOMMENDED B Y THE GENERAL CONVENTION AT PHIL ADELPHIA, IN 1787, at 97 (2d ed. 1836) (statement of Theodore Sedgwick to the Massachusetts ratification convention, January 24, 1788) (emphasis added). Sedgwick's comment was made before the Second Amendment was even proposed, of course, but like others of this era and afterwards, he clearly assumes that individuais in a free state would possess or keep arms.

131. A second reference in this debate to "keep anns" purportedly appears in the right to anns provision of the Constitution of the Conf ederate States of America, but is actually a mistranscription of the original, which is also available for comparison on the relevant page.

132. I do not claim that "keep arms" couldnever be used in a military context, butthat any such uses are rare and there are clear instances-for example, the Nasson and Bellmap statements quoted abovo of "keep arnn" referting to an individual right wholly apart from any active service in an organized militia. See supra notes 81 \& 89 and accompanying text.

133. See infra text accompanying notes $134-37$ 
concerned the right to arns, the phrase "bear arms" was deemed perfectly appropriate.

On June 28, 1856, Representative Alexander $\mathrm{H}$. Stephens proposed a comprehensive list of individual rights as part of a lengthy amendment to the pending bill admitting Kansas into the Union, which stated: "And be it further enacted ... [t]he people of said Territory shall be entitled to the right to keep and bear arms, to the liberty of speech and of the press, as defined in the constitution of the United States, and all other rights of person or property thereby doclared and as thereby defined."134 No mention is made of the militia, and a militia preface like that found in the Second Amendment is absent. "Bear arms" is clearly being used in a nonmilitary context.

In 1861, Representative Clement Vallandigham of Virginia announced his intention to introduce the following legislation, the specific nature of which is not specified:

A bill to regulate and enforce the writ of habeas corpus, and for the better securing the liberty of the citizens;

Also, a bill to enforce the right of the people to be secure in their persons, houses, papers, and effects, against unreasonable searches and seizures;

Also, a bill to secure to the people the right to keep and to bear arms for their defence;

Also, a bill to prescribe the manner of quartering soldiers in private houses in time of war;

Also, a bill to secure the freedom of speech and of the press. ${ }^{135}$

Here too, any militia preface is omitted, and "bear arms" is nonmilitary.

ln 1864, Garrett Davis of Kentucky introduced a resolution containing the following in the Senate:

14. ... That the present executive govemment of the United States has subverted, for the time, in large portions of the loyal States, the freedom of speech, the freedom of the press, and free suffrage, the constitutions and laws of the States and of the United States, the civil courts and trial by jury; it has ordered . . . arbitrary arrests by military officers, not only without warrant, but without any charge or imputation of crime or of fence; and has hurried the persons so arrested from home and vicinage to distant prisons and kept them incarcerated there for an indefinite time; some of whom it discharged without trial, and in utter ignorance of the cause of their arrest and imprisonment; and others it caused to be brought before courts created by itself, and to be tried and punished without law, in violation of the constitutional guarantee to the citizen of his right to keep and bear arms, and of his

134. H.R. J., 34th Cong., Ist Sess. 1126 (1856) (emphasis added).

135. H.R. J., 37th Cong., lst Sess. 102 (1861) (emphasis added). 
rights of property...; all of which must be repudiated and swept away by the sovereign people. ${ }^{136}$

The militia is not mentioned in the litany of alleged violations of individual and personal rights contained in this resolution. The context is entirely nonmilitary.

On April 19, 1872, President Grant addressed Congress in a lengthy message regarding the lawless activities in certain portions of South Carolina. The President listed numerous deprivations of individual rights arising "under the sway of [a] powerful combination[], properly known as [the] 'Ku-Klux-Klan[],' the objects of which were, by force and terror, ... to deprive colored citizens of the right to bear arms . ..."137 Clearly, this reference to a right to bear arms, unaccompanied by a right to keep arms, is outside the militia context. Such abuses of the privileges and immunities of citizens of the United States ${ }^{138}$ is what motivated Congress to propose the Fourteenth Amendment. ${ }^{139}$

True, all these nonmilitary uses of "bear arms" occurred long after the founding, but any assertion that the meaning of "bear anns" had changed at some unspecified interval assumes what must be proved: that the phrase "bear arms" had at the founding an exclusively military meaning-_especially when conjoined with a right to keep arns - that was subsequently broadened to include nonmilitary usages as well. Evidence that such a change occurred is nonexistent.

In this regard, it bears rcpeating that neither the authors nor Garry Wills present a single example of any person from the founding era or immediately thereafter who suggested that the right to "keep and bear arms" was exclusively a military right. While there are numerous examples of the right being used more broadly, such as the statements by Nasson and Belknap quoted above, ${ }^{140}$ there is no record of anyone at the time asserting that the right in the Second Amendment was as narrow or conditioned as the authors claim. Three types of statements could directly support their empirical claim that the original meaning of the right to keep and bear arms was exclusively a military one:

(a) A statement opining that the right to keep and bear arms in the Second Amendment is conditioned on the continued existence of an organized militia; and

(b) A statement explicitly rejecting the importance of an individual right to keep and bear arms, independent of an organized militia; and

136. SEN. J., 38th Cong., lst Sess. 53-54 (1864) (emphasis added).

137. President Ulysses S. Grant, Address Before Congress (Apr. 19, 1872) (emphasis added), in H.R. J., 42d Cong., 2d Sess. $7 ! 6$ (1872).

138. See infra notes $160-73$ and accompanying texi.

139. Michael Kent CuRtis, No State Shall abroge: the FoURteenth AMENDMEnt AND THE BILLOF RIGHTS $7 !-72$ (!986).

140. Seesupranotes $81 \& 89$. 
(c) A statement decrying the Second Amendment for having rejected the individual right to keep and bear arms for one's own self-defense as well as the common defense, in favor of a purely militia-conditioned right.

No such statements are presented. Had Uviller and Merkel done so, it would have made them the first anti-gun-rights scholars to have produced direct evidence of anyone actually holding the view that they claim everyone (or nearly everyone) held. ${ }^{141}$ At this point no such direct evidence is known to exist.

\section{The Structure of the Text}

None of the discussion in Part II is intended to suggest that the term "bear arms" did not also include a military connotation; rather, it is intended only to establish that the term had a broader meaning that the public would reasonably have attributed to the term unless it was expressly qualified, which the Senate declined to do. In addition, Part II illustrates that the right "to keep" arms had no obvious military connotation. If it establishes nothing else, the evidence presented in Part II shows that the unconditioned individual-rights interpretation of the amendment can be found in the historical record and is no invention of the NRA - an organization that Uviller and Merkel mention derisively ${ }^{142}$-or of individual-rights scholars, who the authors repeatedly disparage throughout the book as "advocates" 143 or worse, rather than historians. ${ }^{144}$

At its root, and despite the pages of historical narrative, Uviller and Merkel's argument that the Second Amendment fell silent is not based on any new or direct evidence of original meaning. Apart from ritualistic invocations of "historical context," and various assertions about the meaning of "bear arns," the authors' argument rests almost entirely on their own analysis of its wording. "[A]s a matter of textual analysis," they contend, "we regard it as highly significant that of the several great entitlements enunciated in the first eight Amendments, no other is hedged by a conditional or explanative clause." 145

Elsewhere they claim: "We have ... a clear and unequivocal expression of the linguistic context of the primary right in the introductory phrase that accompanies it." 146 Obviously this is wishful hyperbole. If the right to arms had been made explicitly conditional on participation in the militia, we

\footnotetext{
141. E.g., UVILLER \& MERKEL, supra note 1, at 109 ("To the ratifiers, the right to keep and bear arms was inextricably and exclusively bound to the maintenance of a militia ....").

142. Id. at 205.

143. Id. at 246 n.9.

144. See infra notes $193-98$ and accompanying text.

145. Id. at 23 (emphasis added); see also id. at 35 ("[Hlistorical developments have altered a viral condition for the articulated right to keep and bear arms.") (emphasis added).

146. Id. at 149 (emphasis added).
} 
would not be having this debate. The authors claim that the Second Amendment "guaranteed the right to keep and bear arms in the militia,"147 but the last three qualifying words simply do not appear there or elsewhere.

At one point Uviller and Merkel go so far as to claim: "Had the two statements-regarding the importance of a militia and the right to arms--not been joined in this manner, it might have been possible to argue that even if the first declaration ceases to be true, the second is undiminished."148 Yet none of the precursors of the Second Amendment-including Madison's proposal to Congress-are worded in the grammatical fashion that the authors find so significant. ${ }^{149}$ This does not prevent them from insisting, with equal ardor, that these formulations too "expressly linked" the right to anns to militia service. ${ }^{150}$

The Founders, however, were quite capable of expressly qualifying an individual right -indeed of qualifying a right by military service. They did just this in the Fifth Amendment when they specified the individual right not to be prosecuted without an indictment by the grand jury "except in cases arising in the land or naval forces, or in the Militia, when in actual service in time of War or public danger." Amendment, the Fifth Amendment right to an indictment is expressly conditioned on whether or not a defendant is in actual militia service. And as already noted, the Senate rejected the proposal that would have expressly qualified the exercise of the right to be "for the common defence." 52

Eugene Volokh has chronicled how prefacing constitutional rights with affirnations of purposes was quite common in state constitutions of the day. ${ }^{153}$ For example, the New Hampshire Constitution of 1783 read: "The Liberty of the press is essential to the security of freedom in a State; it ought, therefore, to be inviolably preserved." ${ }^{54}$ Lest any weight be placed on the

147. Id. at 114 (emphasisadded).

148. Id. at 150 .

149. See supra notes 51-59 and accompanying text; 1 ANNALS OF CONG. (Joseph Gales ed., 1789), reprinted in BENNETT B. PATTERSON, THE FORGOTIEN NINTH AMENOMENT 111 (1955) ("The right of the people to keep and bear anns shall not be infinged; a well armed and well regulated militia being the best security of a free country: but no person religiously scrupulous of bearing arms shall be compelled to render military service in person.").

150. UVILLER \& MERKEL, supra note 1, at 83 (referring to the proposal by Noith Carolina at the ratification convention).

151. U.S. CONST. amend. V (emphasis added).

152. UVILLER \& MERKEL, supra note 1 , at 103.

153. Eugene Volokh, The Commonplace Second Amendment, 73 N.Y.U. L. REV. 793, 793-95 (1998) (explaining that these clauses "shed some light" on the Second Amendment in that they (I) show that the Second Amendment is fairly commonplace, rather than strikingly odd; (2) rebut the claim that a right expires once its justification expires; (3) show that operative clauses are often "both broader and narrower than their justification clauses," not dependent on the right's furtherance of its justification clause; and (4) "point to how the two clauses might be read together without disregarding either").

154. N.H. CONST. OF 1783, art. XXII, reprinted in THE COMPLETE B!LI. OF RIGHTS, supra note 43 , at 94 . 
use of a semicolon, the nearly identical passage from the Massachusetts Constitution of 1780 reads: "The Liberty of the Press is essential to the security of freedom in a State, it ought not, therefore, to be restrained in this Commonwealth."

The authors note these state constitutions but dismiss this evidence on the sole ground that "the Second Amendment remains unique among the federal Bill of Rights." 156 But this misses the significance of Professor Volokh's justification-clause evidence for the original public meaning of the Second Amendment. These state-constitutional-rights provisions show that "to eighteenth century ears" (using the authors' phrase), ${ }^{157}$ such language was not uncommon and, so far as we know, was not elsewhere interpreted to limit or condition the right that followed. The authors' denials notwithstanding, this evidence does indeed bear on the original public meaning of the Second Amendment.

None of this is to suggest that the authors' purely textualist analysis is absurd. To the contrary, it is the most plausible argument that the gun-rights opponents have raised to date because they finally concede that the right was one held by individuals and not by state governments. ${ }^{158}$ But neither is their analysis compelling. The fact that the right to bear and keep arms was not expressly conditioned on the Second Amendment's preface strongly suggests that it was not so conditioned. It is precisely when plausible doubts are raised about the proper interpretation of text that evidence of original public meaning becomes important. As we have seen, ample evidence exists to suggest that the right to keep and bear anns existed apart from active service in a militia for the common defense, and reasonable members of the public would have and did so read it. ${ }^{159}$

Even if Uviller and Merkel are correct that the right to keep and bear anns is conditioned on the continued existence of a general militia-of-thewhole, this raises the question of whether they are also right to claim that such a militia no longer exists, a claim to which I shall return after briefly considering two other problems with their treatment.

IV. Was the Right to Keep and Bear Anns Among the Privileges or Immunities of Citizens?

Whatever its proper scope, the right to keep and bear ams (like the rest of the Bill of Rights) was originally meant solely as a constraint on federal

155. MASS. CONST. of $\$ 780$, are. XVl, reprinted in THE COMPLETE BILL OF RiGHTS, supra note 43 , at 94.

156. UVILLER \& MERKEL, supra note 1, at 24.

157. Cf. id at 156 ("twenty-first-centuty ears").

158. See supra note 9 and accompanying text.

159. See supra Part II. 
power; state power was not affected by its adoption. This structural feature of the original Constitution was fundamentally altered by the enactment of the Fourteenth Amendment, which dictates that "[n]o State shall make or enforce any law which shall abridge the privileges or immunities of citizens of the United States..." 160 Was the right to bear arns among these privileges or immunities?

Uviller and Merkel vehemently deny this possibility. ${ }^{161}$ Textually, they argue that because the Fourteenth Amendment does not specifically refer to the right to keep and bear arms as a protected privilege or immunity, the Amendment does not protect this right. ${ }^{162}$ of course no particular right is specified as a privilege or immunity, so this first objection would wipe the clause from the Constitution entirely. Even the Supreme Court in its atrocious five-to-four decision in The Slaughter-House Cases did not go so far as to suggest that the clause had no application whatsoever. ${ }^{163}$

Understanding the original meaning of "privileges or immunities" requires evidence of public meaning. ${ }^{364}$ Unfortunately, the authors rely for their evidence solely on the work of Raoul Berger. ${ }^{165}$ While Berger never made up evidence, as did historian Michael Bellesiles, ${ }^{166}$ a researcher should

I60. U.S. CONST, amend. XIV, $\S 1$.

161. In addition to the textual and historical arguments diseussed here, Uviller and Merkel also stress the fact that courts have uniformly refised to incorporate a personal right to arms into the Founcenth Amendment. UVILLER \& MERKEL, supra note 1, at 198-99, 208. The principal purpose of this debate over the meaning of the Second and Fourteenth Amendments, however, is to discern if this judicial stanee has been correct.

162. Id. at 197-98 ("Regardless of the intentions--even the clearly expressed intentions-of individual Framers, it is the text as ratified that counts, and the text of the Fousteenth Amendment (of course) does not rellect any such puspose."); id. at 198 ("Thus, the Fourteenth Amendment does not proclaim, 'The Bill of Rights, including a personal right to arms for private purposes such as self-defense, shall apply against the states.").

163. See 83 U.S. 36, 79-80 (1872) (citing as privileges of citizens of the United States the rights "to peaceably assemble and petition for redress of grievances, the privilege of the writ of habeas corpus" among others). I eritically examine the majority opinion in Randy E. Bamett, The Proper Scopeof the Police Power, 79 NOTRE DAME L. REV. 429, 466-68 (2004).

164. BARNETt, Restoring, supra note 9, at 89-130.

165. See UVII.LER \& MERKEL, supra note 1, at 200 ('Indeed, Prof essor Raoul Berger reminds us that the desivation of the phrase 'privileges and immunities' strongly suggests that it referred only to rights of trade and eommerce."); id. at 205-06 (ciring "[t]he eminent legal historian, Professor Raoul Berger['s]" conclusion that "the first use of the term--in the Articles of Confederation-made it pretty plain that the privileges referred to were privileges of trade and commerce"); id. at 313 n.120 (attributing to Raoul Berger "a powerfil counterargument, presenting convincing evidence that Howard and Bingham spoke inconsistently, that they frequently contradicted themselves, that most members of Congress expressly rejected these views, and that Howard and Bingham did not cornrrand the respect of the mainstream of the Republican party") (citing RAOUL BERGER, GOVERNMENT BY JUDICIARY 182-85 (2d ed. 1997)).

166. See James Lindgren, Fall From Grace: Arming America and the Bellesiles Scandal, 111 YALE L.J. 2195 (2002) (book review) (pointing out Bellesiles's fabrication of evidence); James Lindgren Justin Lee Heather, Counting Guns in Eanly America, 43 WM. MARV L. REV. 1777, 1839-49 (2002) (demonstrating how Bellesiles misreported the probate records on which he purported to rely and that some of the probate records he claimed to have examined do not exist); 
always independently check sources for context. In this case, Uviller and Merkel fail to address Michael Kent Curtis's refutation of Berger's thesis in No State Shall Abridge: The Fourteenth Amendment and the Bill of Rights, an especially influential book that was also published by Duke. ${ }^{167}$ Though not every scholar has been completely persuaded by Curtis's refitation of Berger's thesis, his conclusions have boen widely accepted and have reshaped the current debate over the original meaning of the Fourteenth Amendment. ${ }^{168}$ Curtis has shown that the primary purpose of the Privileges or Immunities Clause was to revcrse Barron v. Baltimore ${ }^{169}$ and extend federal protection against state violations of the rights contained in the Bill of Rights, especially the right to keep and bear arms. ${ }^{170}$ The lack of any reference to Curtis's work-together with the paucity of their own sourcesseverely undermines the authors' assertions about the Fourteenth Amendment.

Even if Uviller and Merkel were correct about the founding, by 1868 the individual right to arms was certainly not a militia-conditioned one, especially as free blacks and southern Republicans suffered abuses at the hands of white militiamen. As Chief Justice Taney's 1856 opinion in Dred Scott v. Sanford reflects, the right to bear arms was the right "to keep and carry ams"

see also joyce Lee Malcolm, Review: Arming America, 79 TEXAS L. REV. 1657 (2001) (lambasting Bellesiles for "present[ing] a skewed and distorted selection of the records, misquot[ing] contemporary statements and statutes, provid[ing] inaccurate information, and repon[ing] ersoneous counts of the pazticular probate colloctions he spocifically cites"). Though Uviller and Merkel's book appeared anter the disgraced Michael Beliesiles's scholarship began to be discredited, the authors repeatedly cite and discuss his work with favor, even emphasizing at one point Bellesiles's receipt of the now-revoked Bancroft Prize. UVILLER \& MERKEL, supra note 1, at 58-59, 143, 279 n.24, 286 n.78, 287 n.5, 292 n.54, 294 nn.55-57, 295 n.58, 298 n.20, 313 n.110 (all citing Bellesiles's work); id. at 292 n.54 ("In his Bancroft Prize book Arming America...."); Press Release, Columbia University, Columbia's Board of Trustees Votes to Rescind the 2001 Bancroft Prize (Dec. 16, 2002), at http://www.colunbia.edu/cu/news/02/12/bancroft_prize.hnnl (announcing the Docember 7, 2002 vote to rescind the Bancroft Prize originally awarded to Michael Bellesiles and reporting Bellesiles's violation of "basic nomns of acceptable scholarly conduct"). While the authors acknowledge some of Beilesiles's now-vindicated critics in a footnote, in the samı footnote they minimize the significance of the critics' contrary findings. UVILLER \& MERKEL, supra note 1, at 292 n.54 ("Bellesiles's use of the probate data has come under severe scrutiny, and his findings and methods have been sharply criticized .... However, other commentators . . have def ended Bellesiles .... In the interest of faimess, it should be added that Bellesiles's conclusions in Arning America do not depend entirely, or even chiefly, on his analysis of probate data.").

167. CURT7S, supra note 139, at 113-29.

168. See, e.g., Michael Les Benedict, Constitutional History and Constitutional Theory: Reflections on Ackerman, Reconstruction, and the Transformation of the American Constitution, 108 YALE L.J. 2011, 2022 (1999) (characterizing Curtis's contribution to the academic debate on the meaning of the Fourteenth Amendment as "something pretty ciose to" certainty).

169. 32 U.S. 243 (1833).

170. CURTIS, supra note 139, at 173-74. In my writings, 1 have shown how "privileges or immunities" include the natural rights retained by the people as well as additional privileges established by the Bill of Rights. BARNET, RESTORNG, supra note 9, at 60-68. As the right to keep and bear arms is included in the Bill of Rights, however, it is umocessary to accept this historical claim to agree that it was included among the privileges or immunities of citizens. 
wherever one went. ${ }^{171}$ Though Michael Curtis is no gun-rights advocate, he repeatedly references statements that include the right to keep and bear arins as among those rights protected by the Constitution. ${ }^{172}$ For example, the Freedmen's Bureau Act of 1866, approved by a supermajority of Congress over Andrew Johnson's veto, provided that:

[T]he right... to have full and equal benefit of all laws and proceedings concerning personal liberty, personal security, and the acquisition, enjoyment, and disposition of estate, real and personal, including the constitutional right of bearing arms, shall be secured to and enjoyed by all citizens of such State or district without respect to race or color, or previous condition of slavery. ${ }^{173}$

Uviller and Merkel contend that the militia-conditioned "Second Amendment, as adopted by the Founders cannot be surgically reconstructed as a purely personal right, the 'militia' as referred to therein cannot be redefined as bands of private citizens." 174 The copious historical evidence reported by Curtis and others ${ }^{175}$ makes it clear, howcver, that the "incorporation" of individual amendments from the original Bill of Rights into the Due Process Clause is an anachronism. When it comes to the original meaning of the Fourteenth Amendment, the true issue is whether the personal right of bearing arms was among the privileges or immunities of citizens that no state could constitutionally abridge. The overwhelmingly enacted Freedmen's Bureau Act exemplifies the fact that by 1866 the protection of the individual, non-militia-conditioned right to arms for personal security was understood to be a privilege or immunity of citizenship.

\section{Is the Right to Arms Subject to Reasonable Regulation?}

Uviller and Merkel repeatedly assert that finding the right to ams to be an individual right unconditioned on the existence of the militia is a radical claim because such a right would not be subject to reasonable regulation. Thus, they refer to the individual-rights position as entailing an "unbridled right," "176 an "absolute right,"177 "an individual entitlement immune from

171. 60 U.S. $393,417(1856)$.

172. CURTiS, supra note 139 , at 52, 53, 56, 72,88, 104, i1 , 112, 138, 140-41, 164, 167, 178 $79,187,203,217, \& 238$ (discussing references to the right to arms in the context of the drafting and ratifying of the Fourteenth Amendment).

173. 14 Stat. 176-77 (1866) (emphasis added). That the Act protected the right to berr anns solely from discriminatory reatment does not detact from the conclusion that the right is clearly among the privileges or immunities protected by the Fourteenth Amendment. As Curtis has explained, the Amendment protects the right both from laws that discriminate among the people and from laws that abridge equally the privileges or immunities of all citizens. See CURTIS, supra note 139, at 115-20; see also BARNETT, RESTORING, supra note 9, at 195-96.

174. UVILLER \& MERKEL, supra note 1, at 201.

175. See, e.g., STEPHEN P. HALBROOK, FREEDMEN, THE FOURTEENTH AMENDMENT, AND THE RIGHT TO BEAR ARMS, 1866-1876 (1998).

176. UVILLER \& MERKEL, supra note 1 , at 9. 
government curtailment,"178 an "unfettered general license to carry weapons," 179 an "unrestricted right to weapons,"180 an "individual license"181 that "prohibits any interference"182 with a right that would be "immune to government restriction and regulation," 183 and "free of any government control of ams." $" 184$

Despite these polemics, the authors know better. In a footnote ref erring to Laurence Tribe, Akhil Amar, and William Van Alstyne, the authors acknowledge that: "Preeminently, three of the most respected members of the orthodox legal academy to embrace an individual rights reading of the Second Amendment emphasize that this right-like the other individual rights protected in the first eight amendments-should be subject to reasonable regulation." ${ }^{185}$ Disturbingly, the authors fail to mention ${ }^{186}$ that virtually all individual-rights scholars, including the others cited in the same footnote, hold the position that an individual right may be subject to regulation. ${ }^{187}$ Indeed, I know of no individual-rights scholar who claims that the Second Amendment is any more absolute than is the First Amendment.

This unifornity is evidenced by a 1993 advertisement taken out in major journals by "Academics for the Second Amendment" and jointly signed by most individual-rights scholars. ${ }^{188}$ The text of this advertisement appears in an article cited by Uviller and Merkel earlier in the same foomote that concedes the reasonableness of Tribe, Amar, and Van Alstyne. ${ }^{189}$ In this article, which Uviller and Merkel find important enough to criticize elsewhere in their text, ${ }^{190}$ the following sentence of the advertisement is italicized: "Of course, the right to bear arms is no more 'absolute' than is the

177. Id at 11 .

178. Id. at 37 .

179. Id. at 54 .

180. Id. at 83 .

181. Id. ał $86 \cdots 87$.

182. Id. at 169 .

183. Id at 1 .

184. Id. at 197.

185. Id. at 245 n.4 (citing Laurence Tribe \& Akhil Reed Amar, Well-Regulated Militias, and More, N.Y. T1MES, Oct. 28, 1999, at A31, and William Van Alstyne, The Second Amendment and the Personal Right to Arms, 43 DUKE L.J. 1236, 1253-54 (1994)).

186. See UVILLER \& MERKEL, supra note 1, at 254 n.4; see also id. at 37 (describing the individual-rights view as holding that "now and forever, in military pursuits and all others, guns are an individual entitlement immune from govemment curkilment").

187. See, e.g., Don B. Kates, The Second Amendment: A Dialogue, 49 LAW \& CONIEMP. PROBS., Winter 1986, at 143, 145-46 ("[R]easonable gun controls are no more foreclosed by the second amendmen $\neq$ than is reasonable regulation of speech by the first amendment.").

188. An Open Letter on the Second Amendment, NEW REPUBLIC, Mar. 15, 1993, at 15 (advertisement) (endorsing the individual-rights theory of the Second Amendment in a statement signed by, among others, law professors Akhil Amar, Charles Cantrel!, Robert Cotwol, Raymond Diamond, Nicholas Johnson, Sanford Levinson, and Nelson Lund).

189. UVILLER\& MERKEi, supro note 1, at 244 n.4 (citing Bamett \& Kates, supr note 23)

190. UVILLER \& MERKEL, supra note I, at 30 . 
right to speak, to publish, or to assemble."191 This advertisement merely evidences the fact that most individual-rights scholars of the Second Amendment hold a view that the authors mysteriously attribute only to Tribe, Amar, and Van Alstyne. ${ }^{192}$ For this reason, Uviller and Merkel are unable to produce a single example of any individual-rights scholar who contends otherwise.

One suspects that they omit this fact about other individual-rights scholars - whom they never call "scholars," much less "respected"--so they can repeatedly belittle them as "advocates,"193 a "dedicated band of individual rights advocates," 194 an "individual rights brigade"195 or "a growing entourage of individualist interpreters of the Second Amendment." 196 Indeed, when mentioning historian Professor Joyce Malcolm, whose book To Keep and Bear Arms: The Origins of an AngloAmerican Right ${ }^{197}$ was published by Harvard University Press, they go so far as to mention that Bentley College, where she teaches, is "an undergraduate business school in Massachusetts."198 Though individual-rights scholars have come to expect such cheap shots from their academic opponents, it still disappoints.

At this point, some readers may be scratching their heads and wondering, if an individual right to keep and bear arms is subject to reasonable regulation, what is all the excitement about? Why do gun control proponents not simply embrace the original meaning of the right and then propose what regulations they wish? The answer is simple. Were they to do so under current doctrine, such regulations would be subjected to the same scrutiny as laws rcstricting the liberty of speech and the press. Within the modern theory of constitutional rights, as articulated in the famous Footnote Four ${ }^{199}$ of United States v. Carolene Products Co.:

There may be narrower scope for operation of the presumption of constitutionality when legislation appears on its face to be within a specific prohibition of the Constitution, such as those of the first ten

191. Barnett \& Kates, supra note 23, at 1189 (quoting An Open Letter on the Second Amendment, supra note 188) (emphasis added).

192. UVLLER \& MERKEL, supra note 1, at 245 n.4.

193. $J d$. at 246 n.9.

194. Id. at 38 .

195. Id. at 11 .

196. Id. at 53; see also id. at 178 ("[W]e think it regrettable that [Levinson's] unpersuasive thesis has lent respectability to the outlaw libertarians who claim to be the legitimate guardians of American fr eedom.").

197. MALCOLM, supra note 116.

198. UVILLER \& MERKEL, supra note I, at 246 n.9.

199. THE OXFORD COMPANION TO THE SUPREME COURT OF THE UNited STATES 306 (Kertnit L. Hall et al. cds., 1992) (noting in an entry entitled "Footnote Four" that "[w]hat is probably the most renowned footnote in Supreme Court history appeared in a case that would othenwise be forgotten"). 
amendments, which are deemed equally specific when held to be embraced within the Fourteenth. ${ }^{200}$

Despite this injunction, the Second Amendment has never been held by the Supreme Court to be among those specific prohibitions that shift the presumption of constitutionality. ${ }^{201}$ The centrality of the doctrine articulated in Footnote Four to the modern theory of constitutional rights explains why gun-control proponents have expended so much energy to show that the right to keep and bear arms is not "a specific prohibition of the Constitution"202 proponents of gen control wish to avoid the scrutiny that Footnote Four would require.

So here is the position held by individual-rights scholars that Uviller and Merkel fail to acknowledge, much less meet: The fact that the Second Amendment protects an individual right means only that the government must establish the necessity and propriety of its regulations, much as it must do when adopting time, place, and manner restrictions on the freedom of speech. ${ }^{203}$ Further, the individual right bars the complete prohibition and confiscation of all private firearms suitable for self defense, a goal so radical that most gun control enthusiasts deny favoring it. ${ }^{204}$ In other words, properly construed, by permitting reasonable regulation while taking complete prohibition off the table, an individual-rights reading of the Second Amendment prevents rather than proposes a radical policy measure. This is evidenced by the fact that on three occasions Congress has passed a statute expressly recognizing the Second Amendment as protecting an individual right, unconditioned on militia service. ${ }^{205}$

200. 304 U.S. 144, 152 n.4 (1938) (emphasis added).

201. See Presser v. lllinois, 116 U.S. 252, 264-65, 267-68 (1886) (refising to incorporate the Second Amendment and other rights into the Fourteenth Amendment); William F. Lane, Public Endangerment or Personal Liberiy? North Carolina Enacts a Liberalized Concealed Handgun Statute, 74 N.C. L. REV. 2214, 2225 n.76 (stating that, although Presser has never been ovemuled, the Supreme Court has incoiporated aspects of the First, Fourth, Fifth and Sixth Amendments into the Fourteenth Amendment). Federal appellate courts have repeatedly held that the Second Amendment does not apply to state and local gun control laws. See, e.g., Love v. Pepersack, 47 F.3d 120, 123-24 (4th Cir. 1995); Fresno Rifle \& Pistol Club, Inc. v. Van de Kamp, 965 F.2d 723, 729-31 (9ri Cir. 1992); Quilici v. Vill. of Morton Grove, 695 F.2d 261, 269-71 (7th Cir. 1982).

202. For a critique of this modem theory, see BARNETT, RESTORING, supro note 9, at 224-52.

203. See, e.g., United States v. Grace, 461 U.S. 171, 177 (1983) (approving time, place, and manner restrictions of speech only if they "are content-ncural, are narrowly tailored to serve a significant govemment interest, and leavc open ample alternative channels of communication").

204. Though the derial may be disingenuous. See Bamett \& Kates, supra note 23, at 1254-59 (describing the prohihitionist agenda of the gun control movement).

205. Firearms Owners' Protection Act $\S 1$ (b), Pub. L. No. 99-308, 100 Stat. 449 (1986) ("The Congress finds that the rights of citizens ... to keep and bear arms under the second amendment to the Unierd States Constitution [and other rights] . . require additional legislation to correct existing firearms statutes and govemment policies."); Property Requisition Act of 1941, Pub. L. No. 77-274, 55 Stat. 742 ("Nothing contained in this Act shall be construed... to impair or infringe in any manner the right of any individual to keep and bear arms . . . ."); Freedmen's Bureau Act of 1866 , 14 Stat.. 176-77 (1866) (defining "all laws and proceedings conceming personal liberty" to include "the constitutional right of bearing arms"). See generally Stephen P. Halbrook, Congress Inter prets 


\section{Is the Militia Gone?}

Notwithstanding all the evidence presented above, suppose Uviller and Merkel are correct in their claim that the right to keep and bear anns in the Second Amendment was somehow conditioned on service in the militia. Even were this true, their case would still depend on whether the "militia," properly defined, no longer exists. Therefore, Uviller and Merkel's next most important claim after their assertion that the right to bear arns is conditioned on the continued existence of the militia, is that the militia has been discontinued and thus the Second Amendment has fallen silent:

[W]ith no contemporary descendent to inherit the Framers' concept of a republican militia, the incidental right of citizens to bear and to keep the arms necessary to the life of such a militia has atrophied; it has simply fallen silent in the midst of the tumultuous debate on the issue in today's world. ${ }^{206}$

How then do they define the term "militia"?

As we have recounted - and as all scholars agree - the founding generation of Americans conceived of a militia as a group composed of all free white males between eighteen and forty-five (except for the conscientious objectors and others entitled to an exemption), responding willingly, as needed, for the common defence, at the call of local authority, and above all, as a viable altemative to the feared standing army. ${ }^{207}$

Now it is possible to quarrel with this definition. At the end, for example, the authors seem to build into the definition of militia that "above all" it must be a "viable altemative" to a standing army, suggesting that if an entity is not a viable altemative then it is not truly a "militia." If by "viable altemative" the authors have in mind something like an "effective substitute," they cannot mean this seriously. Such a definition runs afoul of the Constitution itself, which affirms both the existence of the militia and the power to create a standing army, as necessary for national defense. ${ }^{208}$ In the

the Second Amendment: Declarations by a Co-Equal Branch on the Individual Right to Keep and Bear Arnss, 62 TENN. L. REV. 597 (1995) (analyzing the congressional reaffirmations of the Second Amendment).

206. UVILLER \& MERKEL, supra note I, at 228.

207. Id. at 157 (footnote omitted).

208. U.S. CONST. art. I, $\S 8$, cl. 15 (giving Congress the power " $[$ t]o provide for calling forth the Militia to execute the Laws of the Union, suppress Insurrections and repel Invasions"); id. art. I, $\S 8, \mathrm{cl} .16$ (giving Congress the power "[t]o provide for organizing, arming, and disciplining, the Militia"); id. art. l, § 8, cL 12 (giving Congress the power "[t]o raise and support Armies"); see id. amend. V, cl. I (mentioning cases "arising in the land or naval forces, or in the Militia, when in actual service in time of War os public danger"). Uviller and Merkel acknowlodge Congress's Article I, Section 8 powers in their book, noting that "[ulnder the Constitution, then, Congress was empowered to raise a professional army" and that "assuming Congress made such provision under Article 1, Section 8, Clause 15, the President would be empowered to call up the several state militia in to the service of the United Statcs to execute the Laws of the Union, suppress Insurrections, and repel lnvasions." UViLLER \& MERKEL, supro note l, at 77. 
Constitution, a well-regulated militia is clearly viewed as an auxiliary to a standing army - the militia can be called into action either to augment the army or to act in their stead when regular forces are preoccupied with other matters or cannot be on the scene as fast as locals. ${ }^{209}$

This caveat aside, Uviller and Merkel acknowledge, correctly, that the original militia to which the Second Amendment refers is not the select militia of the National Guard, ${ }^{210}$ but instead is what they repeatedly call the "militia-of-the-whole." 11 Are they then correct to claim, as they do at considerable length, ${ }^{212}$ that the militia to which the Second Amendment refers no longer exists - "that there is no contemporary, evolved, descendent of the eighteenth-century "militia' on today's landscape"? ${ }^{213}$ It turns out that (if one omits the unwarranted word "evolved" from this claim), according to the current laws of the United States as enacted by Congress, the authors are wrong.

Section 3 II of the United States Code, Title 10, entitled "Militia: composition and classes," reads in its entirety as follows:

(a) The militia of the United States consists of all able-bodied males at least 17 years of age and, except as provided in section 313 of title 32, under 45 years of age who are, or who have made a declaration of intention to become, citizens of the United States and of female citizens of the United States who are commissioned officers of the National Guard.

(b) The classes of the militia are -

(I) the organized militia, which consists of the National Guard and the Naval Militia; and

(2) the unorganized militia, which consists of the members of the militia who are not members of the National Guard or the Naval Militia. ${ }^{2 / 4}$

209. See U.S. CONST. aIt. I, $\S 8, \mathrm{cl} .15$ (giving Congress the power "To provide for cailing forth the Militia to execute the Laws of the Union, suppress lnsurrections and repel Invasions"); id. art. II, $\S 2$, cl. I " The President shail be Conunander in Chief of the Arny and Navy of the United States, and of the militia of the several States, when calied into the actual Service of the United States; ....").

210. See UVILLER \& MERKEL, supra note 1, at 141 ("As far removed as the Cold War National Guard was from the militia described in the Second Amendment ....").

211. E.g., id. at 31, 32, 71, 119, 125, 134.

212. Id. at 109-44 (deviling the decay of the militia of 1789-179] and the origin of the organized militia of today).

213. Id at 157.

214. 10 U.S.C. $\S 311$ (2000) (emphasis added). It should be noted how similar this provision is to the proposal by Henry Knox, which, as the authors note, "proposed to retain the militia-of-thewhole in theozy, but to divide it up into three corps according to age--an advanced corps aged 1820 , a main corps aged $21-45$, and a reserve aged 46-59" with only the advanced corps receiving six weeks of training per year. UVILLER \& MERKEL, supra note l, at 71-72. Compare as well the wording of this statute with that of the Militia Act of 1792 which detined "militia" to include (with some narsow exceptions) "each and every free able-bodied white inale citizen of the respoctive 
So far as federal law is concemed, then, the militia-of-the-whole continues to exist.

Given its obvious relevance to their central claim, what do the authors say about this statute? Actually, they fail to mention it. ${ }^{215}$ Though they note the distinction adopted by statute in 1903 between the "active militia" and "an unorganized militia (the non-enrolled male population between eighteen and forty-five)," article, ${ }^{217}$ that in 1933 "Congress made the National Guard part of the regular anny during peace as well as wartime ... and erased the word 'militia' from the War Department charts, changing the name of the supervisory agency to National Guard Bureau." 218 So far as I know, this claim is not actually false, but it certainly is misleading when used to suggest that the class of militia defined by statute in 1903 as "unorganized militia" no longer exists as a matter of federal law. To the contrary, we have seen that it continues to be recognized in the United States Code. ${ }^{219}$

The authors might respond that this is not the "republican" militia that they and the Founders had in mind: a "well-regulated" militia that is to be properly trained and drilled. ${ }^{220}$ But the federal govermment retains the power to train and discipline the militia if it so chooses. ${ }^{221}$ What the federal government cannot do--if we are to take the preface to the Second Amendment seriously--or at least what the federal government has not done, is abolish the militia altogether rather than to leave it unorganized. Nor can Congress abolish the individual right to arms simply by failing to well-regulate the militia-of-the-whole.

states, resident therein, who is or shall be of the age of eighteen years, and under the age of fortyfive years." Unifonn Militia Act of 1792, ch. 33, § 1, I Stat. 271, 271, repealed by Dick Act, ch. 196, 32 Stat. 775 (1903).

215. Without noting its continued existence in federal law, the authors do connect the "common militia" of the Founders with "the unorganized militia": "In contrast to the National Guard, the unorganized miliva-the shadow of the common militia so extolled by the framers of the Second Amendment - has not been finded by Congress since at least 1903." UVILLER \& MERKEL, supra note 1 , at 143. A lack of funding, however, does not cause the militia to evaporate; rather, the militia is at present "unorganized," as current federal law accurately describes it.

216. Id. at 134.

217. Frederick Bernays Wiener, The Militia Clause of the Constitution, 54 HARV. L. REV. 181, 209 (1940)

218. UVILlER \& MERKEL, supra note 1, at 33, 137, 243 n.99, 290 n.23 ("[L]awmakers "eliminated the word "Militia" from the War Department organization by changing the name of the supervisozy agency to National Guard Bureau."').

219. 10 U.S.C. $\S 31\}$

220. Indeed, the authors mentioned "trained" and "organized" in one of their definitions of "militia": "By militia is meant a trained, organized, and anned collection of qualified citizens, save only those of conscientious sczuple and others exempted fiom service by their states, called together fiom their nommal pursuits to respond to occasional and particular threats, internal or extemal, to community peace." UVILLER \& MERKEL, supre note 1 , at 228.

221. U.S. CONST. art. $1, \S 8, \mathrm{cl}$. 16 (granting Congress the power "[t]o provide for organizing, anning, and disciplining, the Militia"). 
The irony is that, although the authors' entire thesis depends upon the presence in the Second Amendment of the militia preface, they fail to realize that the preface, if taken seriously, would constitutionally bar the abolition of the militia-of-the-whole, thus fatally undermining their claim that the Second Amendment has fallen silent. No matter what Congress might do in the future, the militia-of-the-whole would continue to exist in a constitutional sense, despite its being unorganized and not well-regulated.

Much of their book is devoted to discussing the obsolescence of this body-of-the-whole militia. ${ }^{222}$ They devote chapters to its early ineffectiveness, for example, in stopping the British invasion of Washington in 1812 , colorfully noting that the British soldiers consumed the dinner at the White House that had been prepared for President Madison and his wife. ${ }^{223}$ As for today's militia, they write:

In the years since World War II, the role of a mass reserve in assuring national security has seriously diminished in consideration of the technical complexity of equipment and tasks required of a thoroughly professional modem army, and because nuclear deterrence has made a mass war drawing on all the personnel reserve of the country unlikely. The need for a whole nation in arms has-in all likelihood, permanently--disappeared. ${ }^{224}$

"Indeed," they confidently assert, "it would be difficult to conceive of any institution less necessary to the security of the fifty free states at the beginning of the new millennium than the vanished common militia."225

On September 11 th of 2001 , however, the United States came under aerial attack by planes piloted by foreign nationals. Two planes struck the World Trade Center, destroying it and, with it, thousands of innocent civilians inside. ${ }^{226}$ Another struck the Pentagon, killing hundreds of members of the armed forces. ${ }^{227}$ A fourth plane, United Flight 93, was heading for the nation's capital with the likely target being the White House ${ }^{228}$ or the U.S. Capitol building. It was stopped from reaching its target, but not by the Anny, the Navy, or even the Air Force. Nor was it stopped by the National Guard or the armed eonstabulary of the District of Columbia. After all, these official personnel cannot be everywhere the nation is threatened. No, unlike 1812 , this time the White House was saved from possible destruction by the heroics of members of the "unorganized militia"229 who, after learning on

222. UVILLER\& MERKEL, supra note 1 , a $₫$ 37-144.

223. Id. at 120-21.

224. Id. at 142.

225. Id. at 143 .

226. NAT'LCOMM'N ONTERRORIST ATTACKS UPON THE U.S., THE 9/1 1 COMRUSSION REPORT 7-8 (2004).

227. Id. at $9-10$.

228. Id. at14.

229. 10 U.S.C. $\$ 311(2000)$. 
their cell phones of the attacks by other planes, acted in concert to protect the capital from a second successfil attack on the same moming, at the cost of their own lives. ${ }^{230}$

\section{Conclusion}

Uviller and Merkel's book adds no new historical evidence to the debate over the original meaning of the Second Amendment. Instead, resting their argument almost exclusively on historical "context" and parsing of text, they propose that the right to keep and bear arms was expressly conditioned on its exercise as part of a militia that no longer exists. This interpretation is belied by contempozaneous statements about the nature of the right and the meaning of the Amendment before, during, and after its ratification, ${ }^{231}$ by evidence of later usage, ${ }^{232}$ by the original meaning of the Fourteenth Amendment, ${ }^{233}$ by repeated affirmations by Congress, ${ }^{234}$ and by the current statutes of the United States. ${ }^{235}$

Notwithstanding the authors' opinion that "it would be difficult to conceive of any institution less necessary to the security of the fifty fiee states at the beginning of the new millennium" 236 than the now-disorganized common militia, we may just need the militia again one day, as we did on September IIth. When we do, it may well be under circumstances where it would be better if its members have access to their own weapons to arn themselves. Fortunately, as the evidence shows, the Founders had the foresight to enshrine an individual right of the people to keep and bear arms in the Constitution when they added the Second Amendment. Though it has often been ignored by courts, ${ }^{237}$ and sometimes squelched by scholars like Richard Uviller, William Merkel, or Garry Wills who wish that it was not there, the Second Amendment has not been repealed and it has never fallen silent.

230. NAT'L COMM'NON TERRORIST ATTACKS UPON THE U.S., supra note 226, at 13. Lest 1 be misunderstood, 1 do not offer this example to suggest that aisplane passengers should be anned or that a proper interpretation of the Second Amendment would make disarming them unconstitutional. I offer it only to show that Uviller and Merkel are wrong to assert that, because the nature of warfare has changed, the militia-of-the-whole is no longer, and will never again be, needed to assist in providing for the common defense of the United States. At the least, reasonable people can disagree with their claim.

231. See suprasubpant II(A)-D).

232. See supra notes $61-68,73-78, \& 105-13$ and accompanying text.

233. See supra Part IV.

234. See supra subpart II(E).

235. Seesupra PartV.

236. UVILLER \& MERKEL, supra note !, at 143.

237. For a recent example of a court asserting the militia-conditioned interpretation of the Second Amendment, see Silveira v. Lockyer, 312 F.3d 1052, 1060-61 (9th Cir. 2003) (as amended). The opinion in Silveira had to be amended to correct its original reliance on the discredited work of Michael Bellisiles. Silviera v. Lockyer, 2003 Cal. Daily Op. Serv. 800 (9th Cir. 2003). 
$\star \star \star *$ 